\title{
Alkaloids with Anti-Onchocercal Activity from Voacanga africana Stapf (Apocynaceae): Identification and Molecular Modeling
}

\author{
Smith B. Babiaka ${ }^{1,2, *}$, Conrad V. Simoben ${ }^{3 \oplus}$, Kennedy O. Abuga ${ }^{4}$, James A. Mbah ${ }^{1}$, \\ Rajshekhar Karpoormath ${ }^{5}{ }^{\circ}$, Dennis Ongarora ${ }^{4}{ }^{\circ}$, Hannington Mugo ${ }^{4}$, Elvis Monya ${ }^{6}$, Fidelis Cho-Ngwa ${ }^{6}$, \\ Wolfgang Sippl ${ }^{3}\left(\mathbb{D}\right.$, Edric Joel Loveridge ${ }^{7, *}$ and Fidele Ntie-Kang ${ }^{1,3,8, *(\mathbb{B})}$
}

1 Department of Chemistry, Faculty of Science, University of Buea, P.O. Box 63, Buea CM-00237, Cameroon; ajeck.james@ubuea.cm

2 AgroEco Health Platform, International Institute of Tropical Agriculture, Cotonou, Abomey-Calavi BEN-00229, Benin

3 Institute for Pharmacy, Martin-Luther-Universität Halle-Wittenberg, Kurt-Mothes-Str. 3, 06120 Halle, Germany; veranso.conrad@gmail.com (C.V.S.); wolfgang.sippl@pharmazie.uni-halle.de (W.S.)

4 Department of Pharmaceutical Chemistry, School of Pharmacy, University of Nairobi, Nairobi P.O. Box 19676-00202, Kenya; koabuga@gmail.com (K.O.A.); dbagwasi@gmail.com (D.O.); mugohannington@yahoo.com (H.M.)

5 Department of Pharmaceutical Chemistry, School of Chemistry, University of KwaZulu-Natal, Durban 4001, South Africa; karpoormath@ukzn.ac.za

6 ANDI Centre of Excellence for Onchocerciasis Drug Research, Biotechnology Unit, Faculty of Science, University of Buea, P.O. Box 63, Buea CM-00237, Cameroon; munyane001@gmail.com (E.M.); fidelis.cho@ubuea.cm (F.C.-N.)

Citation: Babiaka, S.B.; Simoben, C.V.; Abuga, K.O.; Mbah, J.A.; Karpoormath, R.; Ongarora, D.; Mugo, H.; Monya, E.; Cho-Ngwa, F.; Sippl, W.; et al. Alkaloids with Anti-Onchocercal Activity from Voacanga africana Stapf (Apocynaceae): Identification and Molecular Modeling. Molecules 2021, 26, 70. https: / dx.doi.org/10.3390/ molecules 26010070

Academic Editor: Derek J. McPhee Received: 16 November 2020 Accepted: 22 December 2020 Published: 25 December 2020

Publisher's Note: MDPI stays neutral with regard to jurisdictional claims in published maps and institutional affiliations.

8 Institute of Botany, Technical University of Dresden, 01217 Dresden, Germany

* Correspondence: babiaka.smith@ubuea.cm or babiakasmith2009@gmail.com (S.B.B.); e.j.loveridge@swansea.ac.uk (E.J.L.); ntiekfidele@gmail.com or fidele.ntie-kang@ubuea.cm (F.N.-K.)

\begin{abstract}
A new iboga-vobasine-type isomeric bisindole alkaloid named voacamine A (1), along with eight known compounds-voacangine (2), voacristine (3), coronaridine (4), tabernanthine (5), iboxygaine (6), voacamine (7), voacorine (8) and conoduramine (9)-were isolated from the stem bark of Voacangaafricana. The structures of the compounds were determined by comprehensive spectroscopic analyses. Compounds 1, 2, 3, 4, 6, 7 and 8 were found to inhibit the motility of both the microfilariae (Mf) and adult male worms of Onchocerca ochengi, in a dose-dependent manner, but were only moderately active on the adult female worms upon biochemical assessment at $30 \mu \mathrm{M}$ drug concentrations. The $\mathrm{IC}_{50}$ values of the isolates are $2.49-5.49 \mu \mathrm{M}$ for microfilariae and 3.45-17.87 $\mu \mathrm{M}$ for adult males. Homology modeling was used to generate a 3D model of the O. ochengi thioredoxin reductase target and docking simulation, followed by molecular dynamics and binding free energy calculations attempted to offer an explanation of the anti-onchocercal structure-activity relationship (SAR) of the isolated compounds. These alkaloids are new potential leads for the development of antifilarial drugs. The results of this study validate the traditional use of $V$. africana in the treatment of human onchocerciasis.
\end{abstract}

Keywords: alkaloids; anti-onchocercal; bisindoles; docking; homology modeling; monoindoles

\section{Introduction}

Voacanga africana Stapf (Apocynaceae) has been applied extensively in traditional Copyright: $\odot 2020$ by the authors. Licensee MDPI, Basel, Switzerland. This article is an open access article distributed under the terms and conditions of the Creative Commons Attribution (CC BY) license (https://creativecommons.org/ licenses/by/4.0/). medicine, particularly in Africa. For example, the root bark of the plant is used to treat diarrhea in Kinshasa, the Democratic Republic of Congo [1], while the stem bark has been used in combination with the sister species $V$. thouarsii in the treatment of heart disease, leprosy, diarrhea, generalized oedema, madness and convulsions in children in Ivory Coast, Cameroon, Ghana and Congo [2,3]. Additionally, the fruits, bark and leaf extracts have been used in Cameroonian ethnomedicine to treat orchitis, ectopic testes and 
gonorrhoea, respectively [4-8]. Of late, Apocynaceous plants have been under scientific investigation. Monoterpenoids and bisindole alkaloids are the major classes of secondary metabolites isolated from this plant family [9-12]. Recently, our research group carried out investigations that led to the identification of the alkaloids voacangine (2) and voacamine (7), from the stem bark of $V$. africana, with both compounds showing activity against Onchocercaochengi [13]. The cattle derived O. ochengi is the best model and closest known relative of $O$. volvulus based on phylogenetic relationship [14]. This was the first report of anti-onchocercalactivity of alkaloids from this plant species. To the best of our knowledge, the majority of the isolated compounds from this plant family have not been screened against onchocerciasis, although the disease still stands as a major public health problem in the developing world [15]. Thus, as part of our research program aimed at investigating new bioactive compounds in anti-onchocercal drug discovery, the present study was undertaken to identify novel inhibitors from this plant using chemical and molecular modeling methods in an attempt to explain their structure-activity relationships.

\section{Results and Discussion}

\subsection{Isolation and Identification of Alkaloids}

The crude methanol extract of $V$. africanawas subjected to silica gel normal phase open column chromatography and elution with a gradient of ethyl acetate in hexane. Repeated column chromatography through Sephadex LH-20, preparative thin-layer chromatography (TLC) yielded a new bisindole alkaloid derivative named voacamine A (1) along with eight known compounds-voacangine (2), voacristine (3), coronaridine (4), tabernanthine (5), iboxygaine (6), voacamine (7), voacorine (8) and conoduramine (9) [16-25] (Figure 1). The structures of the compounds were established based on NMR (Figures S3-S25) analyses as well as by comparison with published data. For 1, infrared and mass spectra (Figures S1 and S2), and optical rotation, were also acquired.

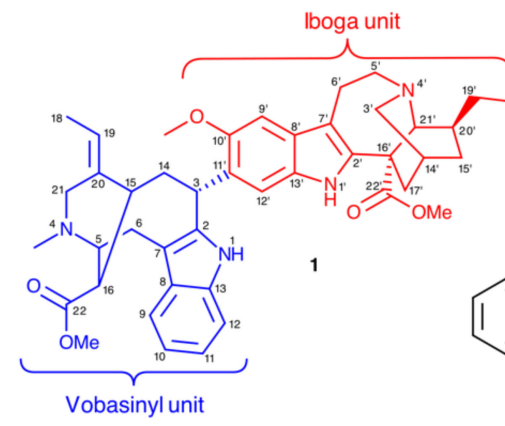

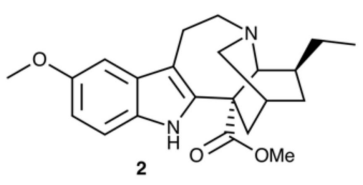

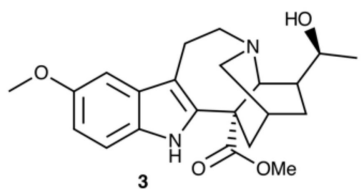<smiles>CC[C@H]1C[C@@H](C)CN2CCc3c([nH]c4ccccc34)C[C@H]1C2=O</smiles>

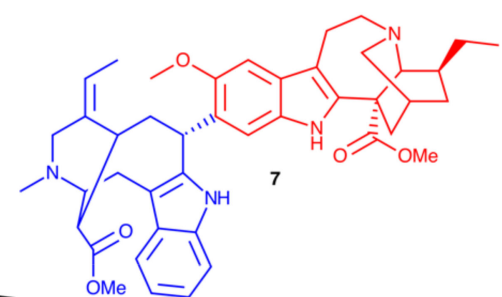<smiles>CC[C@@H]1CC2CC3CN(CCc4c3[nH]c3cc(OC)ccc43)CC21</smiles><smiles>COc1ccc2[nH]c3c(c2c1)CCN1CC3C2CC1CC2[C@H](C)O</smiles>

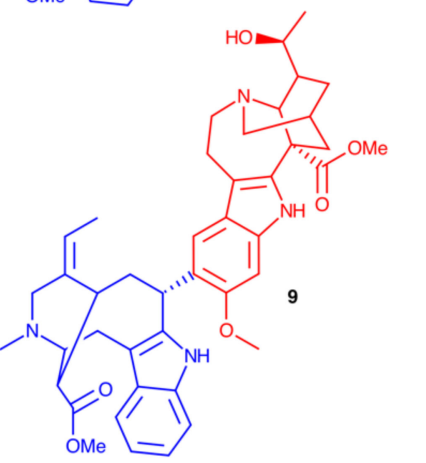

Figure 1. Chemical structures of compounds 1-9. For the bisindoles (1, 7-9), the vobasinyl and iboga subunits are highlighted in blue and red, respectively. 
Compound 1, named voacamine $\mathrm{A}$, was obtained as a cream-colored powder, with a melting point of $222-223{ }^{\circ} \mathrm{C}$ and $\alpha_{\mathrm{D}}-37^{\circ}\left(\mathrm{c}=0.13, \mathrm{CHCl}_{3}\right)$ through crystallization from methanol. This showed a positive reaction with Dragendorff's reagent. The compound was identified by comparing it with an authentic sample of voacamine based on its highperformance liquid chromatography (HPLC) retention times. The UV absorption bands at 228, 287, 295 and $308 \mathrm{~nm}$ indicated 1 to be an indole alkaloid. The major IR absorptions occurred at $3383 \mathrm{~cm}^{-1}$ (indole NH), 2930 and $2856 \mathrm{~cm}^{-1}$ (C-H stretches), $1722 \mathrm{~cm}^{-1}$ (ester), $1463 \mathrm{~cm}^{-1}$ (indole), 1208 and $739 \mathrm{~cm}^{-1}$, and were in line with those expected for bisindole alkaloids. High resolution mass spectrometry revealed a major ion at $m / z 705.4022([\mathrm{M}+$ $\mathrm{H}]^{+}$, calc. 705.4016, $\mathrm{C}_{43} \mathrm{H}_{53} \mathrm{~N}_{4} \mathrm{O}_{5}$ ).

The ${ }^{1} \mathrm{H}$ - and ${ }^{13} \mathrm{C}-\mathrm{NMR}$ data of $\mathbf{1}$ were characteristic of a bisindole alkaloid (Table 1), with almost all chemical shifts very similar to those published for voacamine [18]. The ${ }^{13} \mathrm{C}$-NMR data showed a total of 43 resonances, including those at $\delta 171.5$ (ester carbonyl), 49.9 (ester methyl), 42.4 (N-Me), 118.8, 137.8 (olefinic C-19, C-20) on the vobasinyl subunit, and 11.6, 26.7 (C-18', C-19' , iboga). The ${ }^{1} \mathrm{H}-\mathrm{NMR}$ data of $\mathbf{1}$ showed the presence of two indole $\mathrm{NH}$ groups $(\delta 7.49,7.74,1 \mathrm{H}$ each), an unsubstituted indole moiety $(\delta 7.07-7.57$, $4 \mathrm{H}$, vobasinyl); another, disubstituted, indole ring ( $\delta 6.76$ and $6.95,1 \mathrm{H}$ each, iboga); an aromatic methoxy group $(\delta 4.03,3 \mathrm{H}$, iboga); two methyl esters $(\delta 3.67,2.48$, each $3 \mathrm{H})$; a $\mathrm{N}$-methyl group $(\delta 2.63,3 \mathrm{H})$; and an ethylidene side chain $(\delta 1.69,3 \mathrm{H}$ and $5.36,1 \mathrm{H})$ on the vobasinyl scaffold. ${ }^{15} \mathrm{~N}-\mathrm{HSQC}$ and ${ }^{15} \mathrm{~N}-\mathrm{HMBC}$ (Figure S7) analyses showed no evidence of either subunit being an $\mathrm{N}$-oxide, as the ${ }^{15} \mathrm{~N}$ chemical shifts were inconsistent with this functional group, and neither showed any evidence of a hydroxyl group on C-19', as is seen in 8 and $\mathbf{9 .}$

Notably, all ${ }^{1} \mathrm{H}$ and ${ }^{13} \mathrm{C}$ chemical shifts for the iboga subunit were essentially identical to those observed for 7 [18], allowing us to assign the indole substitution pattern of that moiety to be the same as observed in $\mathbf{7}$ and $\mathbf{8}$, and demonstrating that the vobasinyl moiety is linked to $C-11^{\prime}$ of the iboga moiety. The upfield chemical shift of C-9' $(\delta$ 99.2) is a characteristic of adjacent $\left(\mathrm{C}-10^{\prime}\right)$ oxygenation and confirms the presence of an aromatic methoxy group at $\mathrm{C}-10^{\prime}$ of the iboga subunit. Furthermore, in the NOESY and HMBC (Figure 2) spectra, a H-9' / Ar-OMe NOE and the three-bond correlation from MeO-10' to C-10' were observed.

The ${ }^{1} \mathrm{H}$ and ${ }^{13} \mathrm{C}$ chemical shifts for the vobasinyl subunit were also extremely similar to those of voacamine, except for a significant difference in the chemical shifts of C-2, C-20, $\mathrm{H}-16, \mathrm{H}-19$ and one each of the H-6 and H-21 methylene pairs. The broad resonance at $\delta$ 5.17 was assigned to $\mathrm{H}-3$ on the vobasinyl subunit, which allowed us to confirm linkage of the iboga portion of the bisindole alkaloid to $\mathrm{C}-3$ of the vobasine scaffold, as no alternative linkage point could be found. NOEs to this H-3 resonance were similar in $\mathbf{1}$ to in $\mathbf{7}$ (except where noted below), indicating that the same stereochemistry is observed at C-3.

A

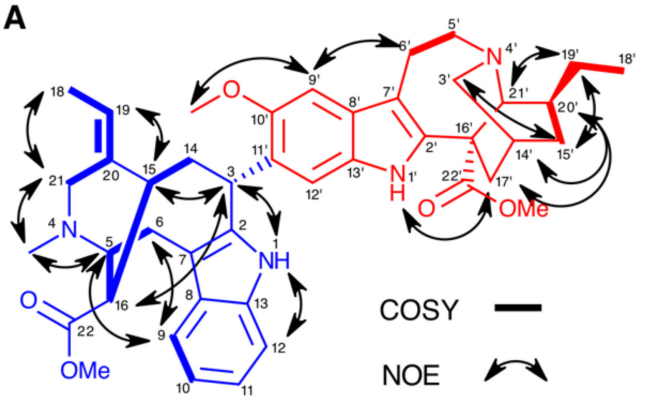

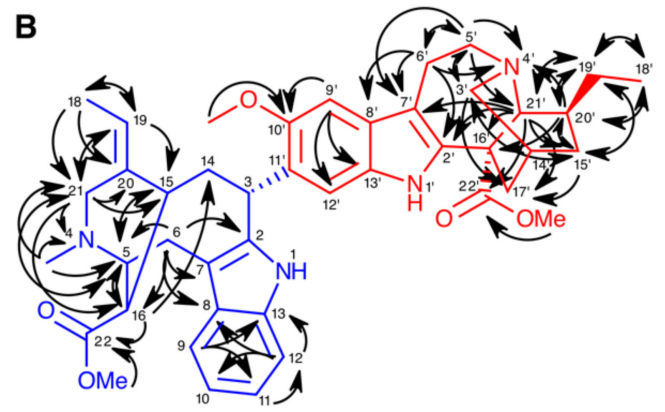

Figure 2. Key NOE (A) and HMBC (B) correlations in compound 1. The vobasinyl and iboga subunits are highlighted in blue and red, respectively. 
Table 1. ${ }^{1} \mathrm{H}(500 \mathrm{MHz})$ and ${ }^{13} \mathrm{C}-\mathrm{NMR}(125 \mathrm{MHz})$ assignments for compound $\mathbf{1}$ in $\mathrm{CDCl}_{3}$.

\begin{tabular}{|c|c|c|c|c|c|c|c|}
\hline No. & $\delta_{H}$ & $\delta_{C}$ & $\delta_{N}$ & $\begin{array}{c}1 \\
\text { No. }\end{array}$ & $\delta_{\mathbf{H}}$ & $\delta_{C}$ & $\delta_{N}$ \\
\hline 1 & $7.74(1 \mathrm{H})$ & & 127.2 & $1^{\prime}$ & $7.49(1 \mathrm{H})$ & & 120.1 \\
\hline 2 & & 137.3 & & $2^{\prime}$ & & 137.2 & \\
\hline 3 & $5.17(1 \mathrm{H})$ & 37.3 & & $3^{\prime}$ & $\begin{array}{l}2.89(1 \mathrm{H}) \\
2.74(1 \mathrm{H})\end{array}$ & 51.9 & \\
\hline 4 & & & 40.8 & $4^{\prime}$ & & & 20.3 \\
\hline 5 & $4.07(1 \mathrm{H})$ & 60.0 & & $5^{\prime}$ & $\begin{array}{l}3.40(1 \mathrm{H}) \\
3.17(1 \mathrm{H})\end{array}$ & 53.1 & \\
\hline 6 & $\begin{array}{l}3.51(1 \mathrm{H}) \\
3.28(1 \mathrm{H})\end{array}$ & 19.5 & & $6^{\prime}$ & $\begin{array}{l}3.12(1 \mathrm{H}) \\
2.99(1 \mathrm{H})\end{array}$ & 22.2 & \\
\hline 7 & & 110.0 & & $7^{\prime}$ & & 110.0 & \\
\hline 8 & & 129.9 & & $8^{\prime}$ & & 127.4 & \\
\hline 9 & $7.57(1 \mathrm{H})$ & 117.4 & & $9^{\prime}$ & $6.95(1 \mathrm{H}, \mathrm{s})$ & 99.2 & \\
\hline 10 & $7.08(1 \mathrm{H})$ & 119.0 & & $10^{\prime}$ & & 150.9 & \\
\hline 11 & $7.07(1 \mathrm{H})$ & 121.6 & & $11^{\prime}$ & & 129.8 & \\
\hline 12 & $7.07(1 \mathrm{H})$ & 109.8 & & $12^{\prime}$ & $6.76(1 \mathrm{H})$ & 110.3 & \\
\hline 13 & & 135.8 & & $13^{\prime}$ & & 130.3 & \\
\hline 14 & $\begin{array}{l}2.58(1 \mathrm{H}) \\
2.02(1 \mathrm{H})\end{array}$ & 36.3 & & $14^{\prime}$ & $1.82(1 \mathrm{H})$ & 27.3 & \\
\hline 15 & $3.80(1 \mathrm{H})$ & 33.6 & & $15^{\prime}$ & $\begin{array}{l}1.70(1 \mathrm{H}) \\
1.11(1 \mathrm{H})\end{array}$ & 32.0 & \\
\hline 16 & $2.75(1 \mathrm{H})$ & 47.0 & & $16^{\prime}$ & & 54.9 & \\
\hline 17 & & & & $17^{\prime}$ & $\begin{array}{l}2.50(1 \mathrm{H}) \\
1.78(1 \mathrm{H})\end{array}$ & 36.4 & \\
\hline 18 & $1.69(3 \mathrm{H})$ & 12.3 & & $18^{\prime}$ & $0.90(3 \mathrm{H})$ & 11.6 & \\
\hline 19 & $5.36(1 \mathrm{H})$ & 118.8 & & $19^{\prime}$ & $\begin{array}{l}1.56(1 \mathrm{H}) \\
1.45(1 \mathrm{H})\end{array}$ & 26.7 & \\
\hline 20 & & 137.8 & & $20^{\prime}$ & $1.31(1 \mathrm{H})$ & 39.0 & \\
\hline 21 & $\begin{array}{l}3.76(1 \mathrm{H}) \\
2.95(1 \mathrm{H})\end{array}$ & 52.6 & & $21^{\prime}$ & $3.53(1 \mathrm{H})$ & 57.2 & \\
\hline $22 \mathrm{CO}$ & & 171.5 & & $22^{\prime} \mathrm{CO}$ & & 175.3 & \\
\hline $22 \mathrm{OMe}$ & $2.48(3 \mathrm{H})$ & 49.9 & & $22^{\prime} \mathrm{OMe}$ & $3.67(3 \mathrm{H})$ & 52.4 & \\
\hline $4 \mathrm{NMe}$ & $2.63(3 \mathrm{H})$ & 42.4 & & $10^{\prime} \mathrm{OMe}$ & $4.03(3 \mathrm{H})$ & 56.1 & \\
\hline
\end{tabular}

In addition to the chemical shift differences, the NOESY (Figure S4) data show key structural differences between 1 and 7. In 7, H-15/H-18 and H-19/H-21 NOEs are observed [18], whereas for 1 these are not seen, and instead H-18/H-21 and H-15/H-19 NOEs are observed, showing that the alkene geometries are different. Similarly, 7 gives NOEs from $\mathrm{H}-16$ to the adjacent $\mathrm{H}-5$ and $\mathrm{H}-15$ only, whereas 1 , in addition to these, gives a clear $\mathrm{H}-3 / \mathrm{H}-16 \mathrm{NOE}$, which indicates that the methyl ester must have the opposite orientation, and, therefore, C-16 the opposite stereochemistry to that observed in 7 [18]. The H-3/H-16 NOE also provides further evidence that $\mathrm{H}-3$ and $\mathrm{C}-16$ are on the same face of the vobasinyl subunit. The stereochemistry at C-20' in the iboga subunit is, however, identical to that in 7 , as evidenced by $\mathrm{H}-3^{\prime} / \mathrm{H}-19^{\prime}$ and $\mathrm{H}-17^{\prime} / \mathrm{H}-20^{\prime}$ NOEs. The structural differences between 1 and 7 also explain the chemical shift differences: C-2 and one H-6 are under the methyl ester in 7, whereas C-20 and one $\mathrm{H}-21$ are under it in $\mathbf{1}$, and the different geometry of the ethylidene group places $\mathrm{H}-19$ in a different environment. The different stereochemistry at C-16 is known (in epi-voacamine), but bisindole alkaloids with a different alkene geometry, to the best of our knowledge, are not. The structure of $\mathbf{1}$ was, therefore, determined as voacamine A. 


\subsection{Anti-Onchocercal Activity}

The isolated compounds were screened for their anti-onchocercal activities against $O$. ochengi using methods described in the literature $[26,27]$. O. ochengiis the best model and closest relative of $O$. volvulus that is cheap and easily available for performing research in chemotherapy and immunology of onchocerciasis. Primary screening was performed to eliminate inactive compounds. Seven of the isolates showed activity against $O$. ocheng $i$ worms in primary screens. Compounds $\mathbf{1}-\mathbf{4}$ and $\mathbf{6}-\mathbf{8}$ were found to inhibit the motility of both the microfilariae (Mf) and adult male worms of $O$. ochengi, in a dose-dependent manner, but were only moderately active on the adult female worms upon biochemical assessment at $30 \mu \mathrm{M}$ drug concentrations (Table 2). Their IC $_{50}$ values were $2.49-5.49 \mu \mathrm{M}$ for microfilariae, and 3.45-17.87 $\mu \mathrm{M}$ for adult males (Table 3).

Table 2. Effect of isolated compounds on O. ochengi worms in primary screens.

\begin{tabular}{cccc}
\hline $\begin{array}{c}\text { * Compounds Tested (at } \\
\mathbf{3 0} \boldsymbol{\mu M})\end{array}$ & $\begin{array}{c}\text { \% Mf Motility Reduction } \\
\text { after } \mathbf{2 4} \mathbf{~ h}\end{array}$ & $\begin{array}{c}\text { \% Adult Male Worm } \\
\text { Motility Reduction after 24 h }\end{array}$ & $\begin{array}{c}\text { \% Adult Female Worm } \\
\text { Death after 120 h }\end{array}$ \\
\hline $\mathbf{1}$ & 100 & 100 & 65 \\
$\mathbf{2}$ & 100 & 100 & 100 \\
$\mathbf{3}$ & 100 & 100 & 50 \\
$\mathbf{4}$ & 100 & 100 & 50 \\
$\mathbf{5}$ & 0 & 0 & 0 \\
$\mathbf{6}$ & 100 & 100 & 50 \\
$\mathbf{7}$ & 100 & 100 & 65 \\
$\mathbf{8}$ & 100 & 100 & 50 \\
$\mathbf{9}$ & 0 & 0 & 0 \\
Ivermectin $(10 \mu \mathrm{g} / \mathrm{mL})$ & 100 & $\mathrm{NA}$ & NA \\
Auranofin $(10 \mu \mathrm{MM})$ & 100 & 100 & 0 \\
$2 \% \mathrm{DSO}$ & 0 & 0 & 0 \\
\hline
\end{tabular}

* Auranofin was used as positive control for adult worm assay, while ivermectin, which is known not to kill adult worms, was used for Mf assay. Dimethyl sulfoxide (DMSO) $2 \%$ was used as negative control. Percentage adult female worm death corresponds to percentage inhibition of formazan formation. NA = Not applicable.

Table 3. $\mathrm{IC}_{50}, \mathrm{IC}_{100}$ and selectivity indices (SI) of isolates on O. ochengi microfilariae and adult worms, and monkey kidney epithelial cells (LLC-MK2) in secondary screens.

\begin{tabular}{|c|c|c|c|c|c|c|c|c|}
\hline & Mf & $\begin{array}{l}\text { Adult Male } \\
\text { Worm }\end{array}$ & $\begin{array}{l}\text { Adult } \\
\text { Female } \\
\text { Worm }\end{array}$ & $\begin{array}{c}\text { Monkey Kidney } \\
\text { Cells } \\
\text { (LLC-MK2) }\end{array}$ & Mf & $\begin{array}{l}\text { Adult Male } \\
\text { Worm }\end{array}$ & $\begin{array}{l}\text { Adult } \\
\text { Female } \\
\text { Worm }\end{array}$ & $\begin{array}{c}\text { Monkey Kidney } \\
\text { Cells } \\
\text { (LLC-MK2) }\end{array}$ \\
\hline & \multicolumn{4}{|c|}{1} & \multicolumn{4}{|c|}{2} \\
\hline $\mathrm{IC}_{50}(\mu \mathrm{M})$ & 3.69 & 4.45 & - & $\geq 30$ & 5.49 & 9.07 & - & $\geq 30$ \\
\hline $\mathrm{IC}_{100}(\mu \mathrm{M})$ & 7.38 & 8.90 & $>30$ & - & 10 & 20 & $>30$ & - \\
\hline SI & 8.13 & 6.74 & 3 & & 5.46 & 3.30 & $4^{2.83}$ & \\
\hline $\mathrm{IC}_{50}(\mu \mathrm{M})$ & 4.34 & 8.07 & - & $\geq 30$ & 4.21 & 8.68 & - & $\geq 30$ \\
\hline $\mathrm{IC}_{100}(\mu \mathrm{M})$ & 8.68 & 16.14 & $>30$ & - & 8.42 & 17.36 & $>30$ & - \\
\hline SI & 6.91 & 3.71 & 6 & & \multicolumn{4}{|c|}{7} \\
\hline $\mathrm{IC}_{50}(\mu \mathrm{M})$ & 4.72 & 9.07 & - & $\geq 30$ & 2.49 & 3.45 & - & $\geq 30$ \\
\hline $\mathrm{IC}_{100}(\mu \mathrm{M})$ & 9.44 & 18.14 & $>30$ & - & 10 & 10 & $>30$ & - \\
\hline SI & 6.35 & 3.30 & 8 & & & & & \\
\hline $\mathrm{IC}_{50}(\mu \mathrm{M})$ & 2.49 & 3.45 & - & $\geq 30$ & & & & \\
\hline $\mathrm{IC}_{100}(\mu \mathrm{M})$ & 4.98 & 6.90 & $>30$ & - & & & & \\
\hline SI & 12.04 & 8.69 & & & & & & \\
\hline
\end{tabular}

At $10 \mu \mathrm{M}$, amocarzine and FDA approved auranofin, a gold conjugated compound, previously shown to be a macrofilaricide and a current arthritis drug (positive control, [27]), also produced 100\% inhibition of formazan formation in adult female worms at $120 \mathrm{~h}$ of incubation. 


\subsection{Molecular Modeling of Secondary Metabolites}

\subsubsection{Computation of Pharmacokinetic-Related Properties}

Several physicochemical properties of the identified compounds were computed, particularly those related to drug metabolism and pharmacokinetics, using the QikProp software (Schrodinger 2018). The obtained values were compared with values reported for the same parameters for $95 \%$ of known drugs. Selected computed values are shown in Table 4. The number of properties for which the computed values for compounds $\mathbf{1}$ to $\mathbf{9}$ fall outside the recommended range for $95 \%$ of known drugs are marked as \#stars. For 5 of the identified compounds (2 to 6), the values of \#stars were reported as zero. This implied that all the computed properties related to drug metabolism and pharmacokinetics (DMPK) for these compounds (only the monoindoles) fell within the required range for $95 \%$ of known drugs.

Regarding the compounds with properties falling out of the required range, the bisindoles (compounds $\mathbf{1}$, and 7-9), the properties that fell outside the required range (above $1000.0 \AA^{2}$ ) are marked with an asterisk in Table 4. For example, these compounds show particularly high solvent accessible surface areas, which would not be ideal for crossing the cell membrane if administered as drugs [28]. A highly polar surface will not easily penetrate the cell membranes and would require special transporters, thereby leading to a low concentration of the compound in the cells. The same trend holds for the hydrophobic component of the SASA of the same compounds (above $750 \AA^{2}$ ). In this case, the higher hydrophobic surface plays a negative role in the interaction of these molecules with water (a polar solvent), hence lower solubility. The logS value is expected to range from -6.5 to 5 for most drugs. In the case of these compounds, the computed aqueous solubilities are weak (all below -6.5), implying that the only hope of them being developed into drugs would be by the introduction of polar functional groups, which could render them less hydrophobic and more polar, or to fragment them into monoindoles. The higher hydrophobicities of the bisindoles is also demonstrated in their higher logP values (all above the required maximum of 5 for orally absorbed drugs according to Lipinski's rules [29]). The same trend is observed for the molar volumes (all bisindoles with volumes higher than the maximum of $2000 \AA^{3}$ for the majority of known drugs). Compounds known to block human-ether-a-go-go $\mathrm{K}^{+}$channels have a high tendency to provoke cardiac arrhythmia and could be fatal $[30,31]$. Thus, computed logHERG values are often used as indicators of toxicities of compounds. In the case where this value is less than -5 , the compound is not encouraged to be further developed. This is the case of the bisindoles, all computed $\operatorname{logHERG}$ values were less than -5 . This, coupled with the low MDCK permeabilities (an indicator of poor drug permeability, with most of the bisindoles showing less than or almost equal a value of 25 , signifying weak permeability [32]), and higher number of expected metabolic reactions (10 reactions each, signifying their instability in the body) all indicate that the bisindoles are not suitable for further drug development. In addition, they have higher binding affinities to plasma proteins. In this case, the predicted binding affinities to human serum albumin (HSA) were higher than the expected maximum. In general, binding to plasma proteins limits the amount of the drug to be distributed in general circulation [33]. Furthermore, only these bisindoles violated the general rules of thumb ("Rule of Five" and "Rule of Three"), which are general guidelines for selecting orally available drugs.

\subsubsection{Homology Modeling Model Development}

To date, there is no available protein structure for the thioredoxin reductase of O. ochengi in the Protein Data Bank [34]. So, a multiple sequence alignment to check the identified conserved moieties for the homologous protein sequences was performed. The percentage sequence identity and similarity values to our target, compared with templates, are shown in (Figure S24). The ligand present in the template structure was transferred to the target during the homology model development process via a slight modification of the modeler script. The structural template 4JNQ_A with a dihydroflavine- 
adenine dinucleotide (to define and construct the binding pocket) was selected and used for the generation of homology models. Estimation of model quality was an important aspect in selecting the best model among the 100 models that were built. The final model (Figure 3) was selected based on the DOPE scoring function of the modeler program, used in the generation of the models. The Ramachandran plot $(\varphi / \psi)$ distribution of the backbone conformation angles for each of the residues of the refined structure revealed that $\sim 98.0 \%$ and $\sim 2.0 \%$ were expected in the favored and allowed regions (Figure S25). The choice of model was considered as satisfactory and reliable to advance our study.

Table 4. Computed molecular descriptors for the assessment of the drug metabolism and pharmacokinetics (DMPK) profiles of the major isolated metabolites and the recommended range for $95 \%$ of known drugs.

\begin{tabular}{|c|c|c|c|c|c|c|c|}
\hline Metabolite & a \#stars & b CNS & ${ }^{\mathrm{c}} \mathrm{MW}$ (Da) & d SASA & e FOSA & ${ }^{\mathrm{f}}$ FISA & g Volume \\
\hline 1 & $9 *$ & 1 & 706.9 & $1067.5^{*}$ & $786.3 *$ & 80.0 & 2140.6 * \\
\hline 2 & 0 & 2 & 368.5 & 626.1 & 480.8 & 28.0 & 1171.6 \\
\hline 3 & 0 & 1 & 384.5 & 642.5 & 461.5 & 64.5 & 1191.3 \\
\hline 4 & 0 & 2 & 338.4 & 588.5 & 387.1 & 28.0 & 1094.4 \\
\hline 5 & 0 & 2 & 368.5 & 635.5 & 485.4 & 31.7 & 1175.4 \\
\hline 6 & 0 & 1 & 384.5 & 642.4 & 461.5 & 64.5 & 1191.3 \\
\hline 7 & $9 *$ & 1 & 706.9 & $1057.7^{*}$ & $781.6^{*}$ & 71.7 & 2130.5 * \\
\hline 8 & $10 *$ & 1 & 722.9 & $1091.1 *$ & $769.0 *$ & 119.3 & $2156.9 *$ \\
\hline 9 & $10 *$ & 1 & 722.9 & $1089.4^{*}$ & $768.4 *$ & 115.5 & $2163.6 *$ \\
\hline Metabolite & ${ }^{\mathrm{h}}$ HBD & ${ }^{\mathrm{i}} \mathrm{HBA}$ & ${ }^{j} \log P$ & ${ }^{k} \log S$ & ${ }^{1} \operatorname{logHERG}$ & ${ }^{\mathrm{m}}$ Caco-2 & ${ }^{n} \log B B$ \\
\hline 1 & 1 & 9 & $7.2 *$ & $-8.0 *$ & $-8.66^{*}$ & 26.8 & 0.2 \\
\hline 2 & 0 & 4 & 4.5 & -4.4 & -5.11 & 1340.2 & 0.5 \\
\hline 3 & 1 & 5 & 3.7 & -4.1 & -5.31 & 604.0 & 0.1 \\
\hline 4 & 0 & 3 & 4.5 & -4.3 & -5.15 & 1341.8 & 0.6 \\
\hline 5 & 0 & 4 & 4.5 & -4.6 & -5.29 & 1237.7 & 0.5 \\
\hline 6 & 1 & 5 & 3.7 & -4.1 & -5.31 & 604.0 & 0.1 \\
\hline 7 & 1 & 9 & $7.2 *$ & $-7.8^{*}$ & $-8.62 *$ & 32.1 & 0.3 \\
\hline 8 & 2 & 10 & 6.2 & $-7.5^{*}$ & $-8.89 *$ & 11.4 & -0.4 \\
\hline 9 & 2 & 10 & 6.2 & $-7.5^{*}$ & $-8.86 *$ & 12.4 & -0.4 \\
\hline Metabolite & ${ }^{\circ}$ MDCK & $p \log K_{p}$ & q \#metab & ${ }^{\mathrm{r}} \log \mathrm{K}_{\mathrm{HSA}}$ & s PHOA & ${ }^{t} \operatorname{Ro5}$ & u Ro3 \\
\hline 1 & 70.4 & -6.1 & $10 *$ & $2.49 *$ & 92.7 & $2 *$ & $2 *$ \\
\hline 2 & 282.3 & -3.4 & 2 & 0.89 & 50.3 & 0 & 0 \\
\hline 3 & 133.9 & -4.0 & 3 & 0.63 & 69.0 & 0 & 0 \\
\hline 4 & 268.8 & -3.3 & 1 & 0.91 & 42.0 & 0 & 0 \\
\hline 5 & 836.0 & -3.5 & 2 & 0.90 & 50.1 & 0 & 0 \\
\hline 6 & 340.4 & -4.0 & 3 & 0.63 & 69.1 & 0 & 0 \\
\hline 7 & $24.1 *$ & -5.9 & $10 *$ & $2.47 *$ & 95.1 & $2 *$ & $2 *$ \\
\hline 8 & $9.2 *$ & -6.7 & $10 *$ & $2.09 *$ & 118.8 & $2 *$ & $3 *$ \\
\hline 9 & 26.4 & -6.6 & $10 *$ & $2.11 *$ & 118.1 & $2 *$ & $3 *$ \\
\hline
\end{tabular}

${ }^{*}$ Property which falls outside the recommended range for $95 \%$ of known drugs; ${ }^{a}$ number of computed properties which fall outside the required range for $95 \%$ of known drugs (recommended range 0 to 5 ); ${ }^{b}$ activity in the central nervous system in the scale -2 (inactive) to +2 (active); ${ }^{\mathrm{c}}$ molar weight (range for $95 \%$ of drugs: $130-725 \mathrm{Da}$ ); ${ }^{\mathrm{d}}$ the solvent accessible surface area (recommended range 300.0 to $1000.0 \AA^{2}$ ); e The hydrophobic component of the solvent accessible surface area (recommended range 0.0 to $750.0 \AA^{2}$ ); ${ }^{\mathrm{f}}$ the hydrophilic component of the solvent accessible surface area (recommended range 7.0 to $330.0 \AA^{2}$ ); ${ }^{g}$ total volume of molecule enclosed by solvent-accessible molecular surface, in $\AA^{3}$ (probe radius $1.4 \AA$ ) (range for $95 \%$ of drugs: 500 to $2000 \AA^{3}$ ); ${ }^{\text {h }}$ number of hydrogen bonds donated by the molecule (range for $95 \%$ of drugs: 0 to 6 ); ${ }^{i}$ number of hydrogen bonds accepted by the molecule (range for $95 \%$ of drugs: $\left.2-20\right) ;{ }^{j}$ logarithm of partitioning coefficient between $n$-octanol and water phases (range for $95 \%$ of drugs: -2 to 6.5 ); ${ }^{k}$ the predicted aqueous solubility, with $\mathrm{S}$ in $\mathrm{mol} / \mathrm{dm}^{3}$ (range for $95 \%$ of drugs: -6.5 to 0.5 ); ${ }^{1}$ predicted IC 50 value for blockage of HERG K+ channels (concern $<-5$ ); ${ }^{m}$ predicted apparent Caco-2 cell membrane permeability in Boehringer-Ingelheim scale, in nm/s (range for $95 \%$ of drugs: $<5$ low, $>500$ high); ${ }^{n}$ logarithm of predicted blood/brain barrier partition coefficient (range for $95 \%$ of drugs: -3.0 to 1.0 ); ${ }^{\circ}$ the predicted apparent MDCK permeability in $\mathrm{nm} / \mathrm{s}(<25$ poor, $>500$ great); $\mathrm{P}$ the predicted skin permeability (range for $95 \%$ of drugs: -8.0 to -1.0$) ;{ }^{\mathrm{q}}$ number of likely metabolic reactions (range for $95 \%$ of drugs: 1-8); ${ }^{\mathrm{r}}$ Logarithm of predicted binding constant to human serum albumin (range for $95 \%$ of drugs: -1.5 to 1.5$) ;{ }^{s}$ the predicted percentage human oral absorption ( $>80 \%$ high, $<25 \%$ poor); ${ }^{t}$ number of violations of Lipinski's "Rule of Five" (recommended maximum of 4); ${ }^{\mathrm{u}}$ number of violations of Jorgensen's "Rule of Three" (recommended maximum of 3). 


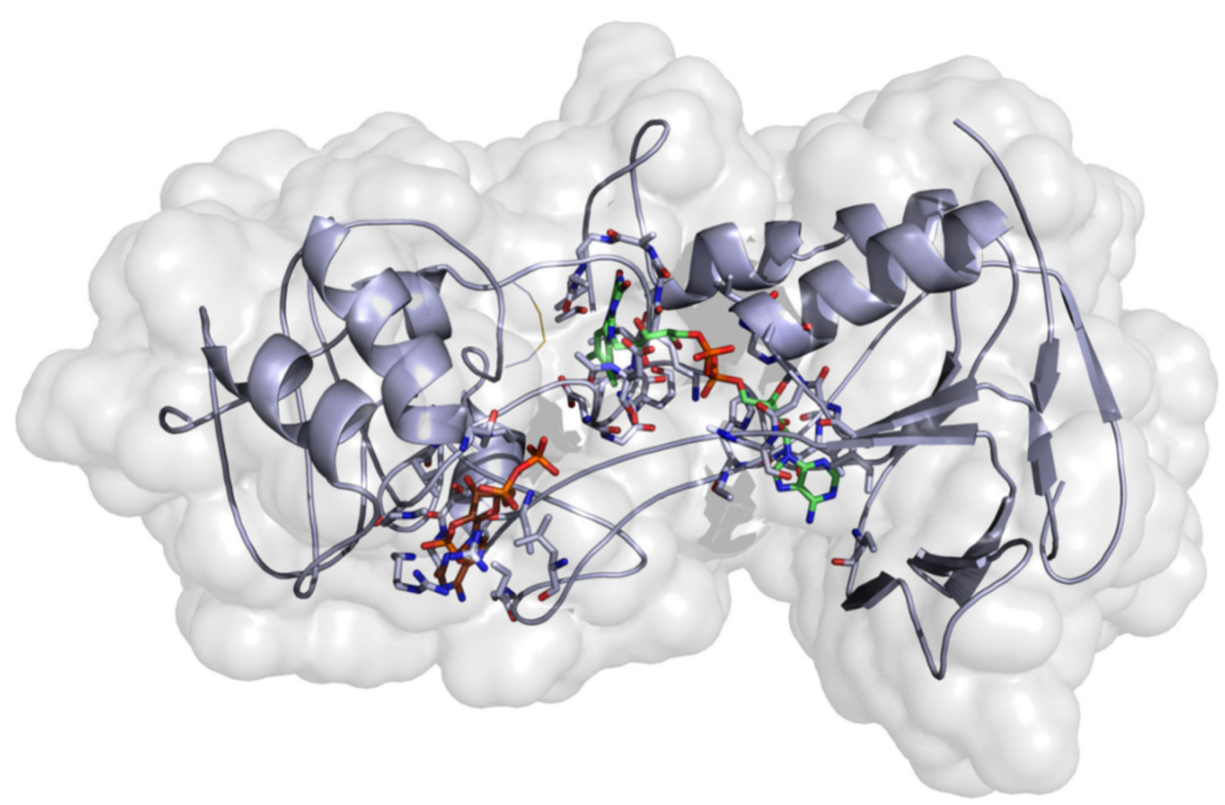

Figure 3. Homology model of thioredoxin reductase of O. ochengi.

Evaluation of the Stability of the Generated Homology Model

To fully explore the generated model and use it for further in silico procedures, the model was prepared and subjected to two energy minimization steps. A 20 ns molecular dynamic simulation run using the Amber software was used to evaluate the stability of the resulting homology model [35]. Visual inspection of the trajectory of the homology model confirmed it reached an equilibrium at $\sim 4$ ns into the molecular dynamic simulation run with an rmsd value of about 2.5. Figure 4 shows that the rmsd plot of the backbone heavy atoms of the conformations sampled during the simulation time was stable.

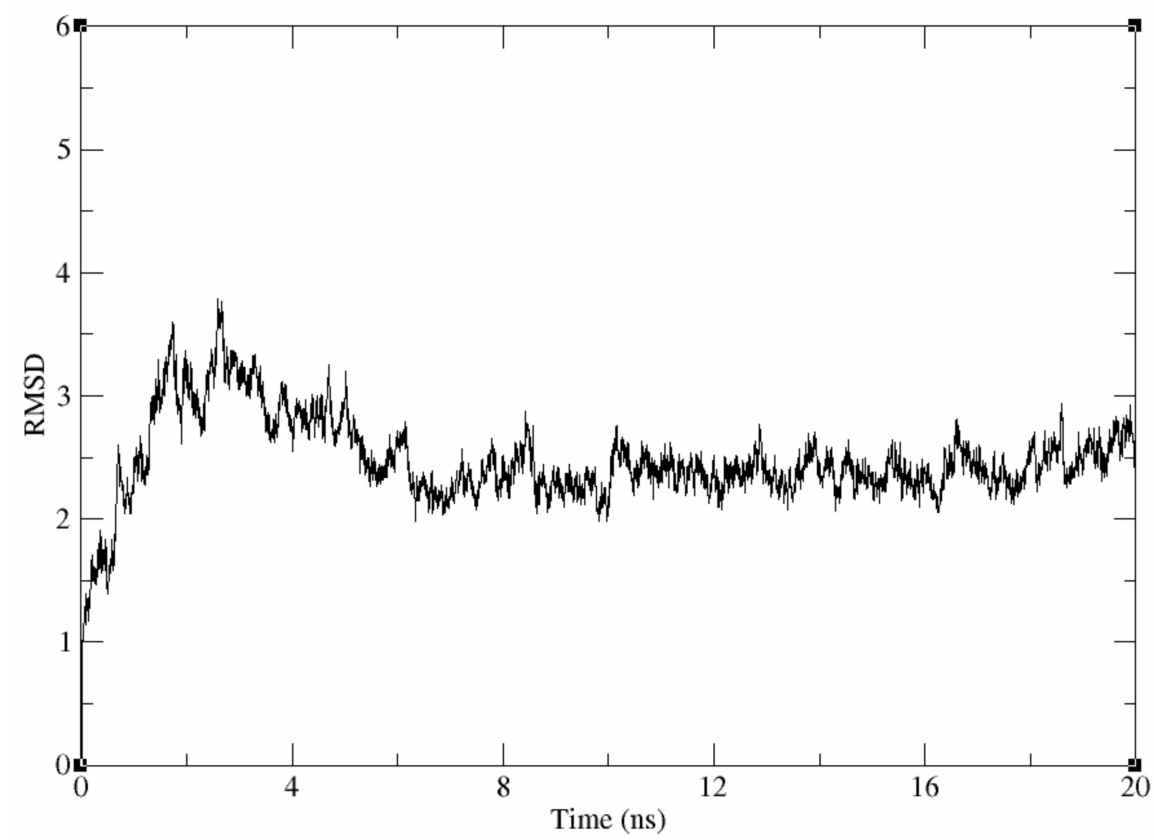

Figure 4. Root mean square deviation (rmsd) of generated homology sampled during 20ns molecular dynamics (MD) simulation with respect to the initial structure versus simulation time.

\subsubsection{Docking}

To explain the observed experimental reported activities of the isolated indole alkaloid, an attempt was made to understand their binding mode and interactions with 
the thioredoxin reductase model generated for O. ochengi. Docking scores and estimated minimization energies of the protein-ligand complexes for the compounds docked into the target site of $O$. ocheng $i$ thioredoxin reductase, using rigid ligand docking within the active site of the generated model, are tabulated (Table 5). The docking poses of the ligands within the protein binding site in the putative binding mode are shown in Figure 5.

\subsubsection{Binding Free Energy Calculations}

To further explore the SAR, the free energy of binding of each ligand to the receptor in the putative binding mode was calculated, along with its electrostatic $\left(\mathrm{E}_{\text {ele }}\right)$, van der Waals $\left(\mathrm{E}_{\mathrm{vdw}}\right)$ and solvation $\left(\mathrm{E}_{\mathrm{sol}}\right)$ components. These are included in Table 6.

Compound 8 was not included in the calculation, since both the vobasinyl and the iboga moieties of this compound are represented in the other structures, e.g., the vobasinyl moiety of compound 8 is the same as that of compounds 7 and 9, i.e., 7a, while the iboga moiety of compound $\mathbf{8}$ is the same as that of compound 9. The computed $\Delta \mathrm{G}_{\mathrm{bind}}$ energy values showed the lowest binding affinity (tightest binding) for compound 7 towards the target (Table 6), with no clear-cut differences in binding affinities of the monoindoles towards the targets, when compared with the bisindoles. Amongst the monoindoles (compounds 2 to 6), compounds 2 and 3 showed much tighter binding compared to compounds 3 to 6 . Meanwhile, among the bisindoles, the lowest affinities were seen in compounds $\mathbf{1}$ and 7. In general, the greatest contribution towards the computed binding free energies, which were approximately 2 - to 5-fold that ofthe van der Waals interactions in the monoindoles and 2and 6-fold in the bisindoles, was electrostatic. Furthermore, the computed affinities that had a greater electrostatic contribution to binding free energy led to better affinities. Since van der Waals contributions are generally more important for hydrophobic molecules while the electrostatic contribution to binding affinity is more important for polar compounds, it was clear that the introduction of more polar groups to the monoindoles would show better prospects towards binding to the thioredoxin reductase target of $O$. ochengi.

\subsubsection{Structure-Activity Relationships}

From Table 3 , it can be observed, in terms of $\mathrm{IC}_{50}$ values, that:

- Compound 1 is more active than compound 2, being $\sim 2$ fold more active in both Mf and adult male worms. In our discussion, the activities against adult female worms were ignored, since the experimental activities were limited to a few dotted cases.

- The measured activities of the bisindoles (1, 7 and 8, possessing a vobasinyl unit) were much better than those of the mono indoles (2-4 and 6).

- Compound 5 was almost inactive in all assays and is not included in Table 3 and this discussion.

The activities of all tested bisindoles lie within the same range and are twice as active as all the tested monoindoles. Among the monoindoles, it was noted that since they lack the vobasinyl unit, they all have much weaker activities against both $\mathrm{Mf}$ and adult males than the bisindoles. In the continuation of our discussion, we shall refer to the vobasinyl unit of compound $\mathbf{1}$ as $\mathbf{1 a}$, while the vobasinyl unit of compound $\mathbf{7}$ would be referred to as $7 \mathbf{a}$ and the iboga unit of compound $\mathbf{9}$ would be referred to as $\mathbf{9 b}$.

Among the monoindoles (2 to 6), the least active is compound 5. Compound 4 is most active against Mf, while 3 is most active in adult males (Table 3). This shows that the OMe and $\mathrm{OH}$ groups do not play any role in the activity. On the contrary, the ester group (present in both the most active compounds 2 and 3 ) is absent in the least active monoindoles (5 and 6). This ester group interacts with the triad (Gly116, Ala117 and Ala114) in the docking pose of compound 2 (Figure 5B), making a H-bond with Gly116. The same ester group in the iboga unit of compound 7 makes the same interaction with the same triad (Figure S30A). The docking pose of compound 4 (Figure 5D) also shows the ester group interacting with the Gly116, Ala117 and Ala114 triad, which is an indication that the monoindoles that lack this ester group (compounds 5 and 6) would miss this interaction and, hence, be less active than their counterparts (2-4) in both Mf and adult male worms. The ester group is 
also present in all vobasinyl units of the bisindoles, but only interacts with Asn249 in the docking pose of compound $\mathbf{1}$ (Figure 5A), contrary to compounds $\mathbf{2}$ and $\mathbf{3}$.

Table 5. Docking scores of the isolated compounds and their moieties towards the O. ochengi thioredoxin reductase target and minimization energies of the protein-ligand complexes (including electronic, solvation and van der Waals components).

\begin{tabular}{|c|c|c|}
\hline Compound & Minimization Energy (Amber12, kcal/mol) & Docking Score $\left(\mathrm{SP}^{*}, \mathrm{kcal} / \mathrm{mol}\right)$ \\
\hline 1 & -30.48 & -4.25 \\
\hline $1 \mathrm{a}^{\mathrm{a}}$ & -32.02 & -5.07 \\
\hline $1 b^{b}$ & -32.33 & -4.89 \\
\hline 2 & -32.01 & -5.07 \\
\hline 3 & -28.94 & -5.26 \\
\hline 4 & -26.79 & -4.54 \\
\hline 5 & -28.72 & -4.80 \\
\hline 6 & -28.88 & -5.26 \\
\hline 7 & -30.43 & -4.25 \\
\hline $7 \mathrm{a}^{\mathrm{a}}$ & -31.99 & -5.08 \\
\hline $7 b^{b}$ & -21.83 & -4.18 \\
\hline 8 & -28.41 & -4.73 \\
\hline $8 a^{a}$ & -30.34 & -5.28 \\
\hline $8 \mathbf{b}^{\mathrm{b}}$ & -21.91 & -4.18 \\
\hline 9 & -40.53 & -5.20 \\
\hline $9 \mathrm{a}^{\mathrm{a}}$ & -29.65 & -5.03 \\
\hline $9 b^{b}$ & -21.59 & -4.18 \\
\hline Auranofin & -47.38 & -6.37 \\
\hline
\end{tabular}

* Standard Precision; ${ }^{a}$ the iboga unit; ${ }^{\mathrm{b}}$ the vobasinyl unit.

A

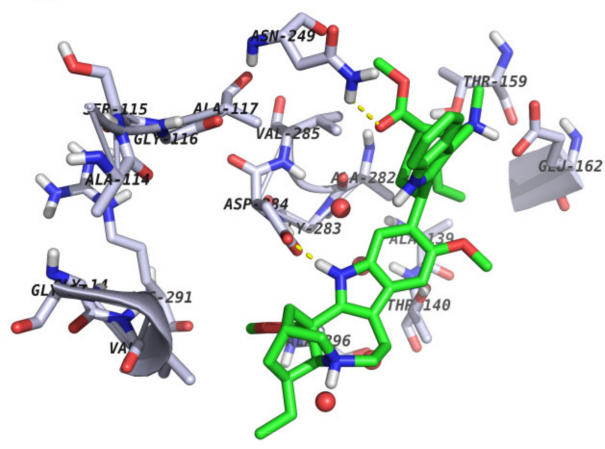

C

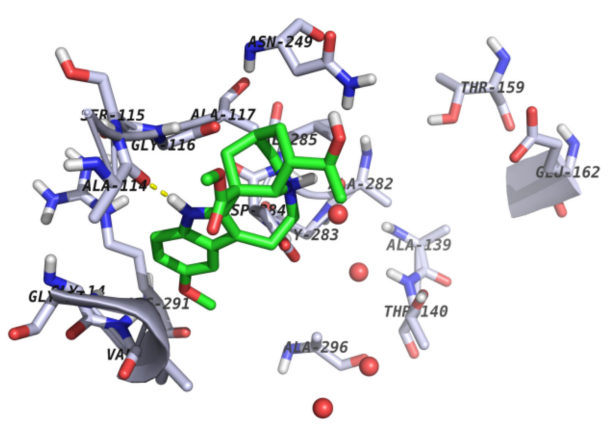

B

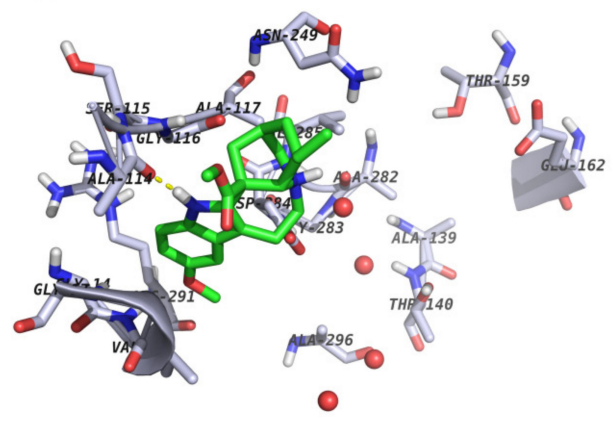

D

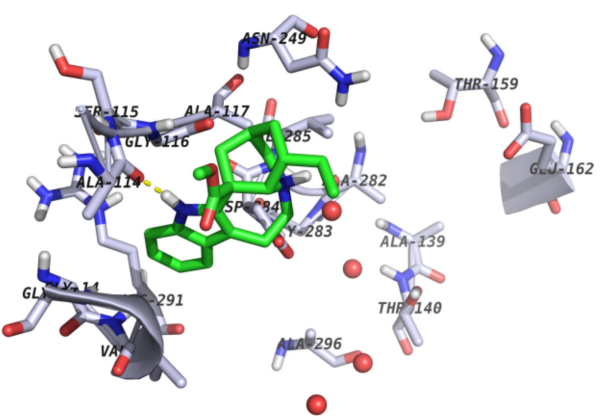

Figure 5. Binding interactions between the binding site with amino acid side-chains with the compounds; (A) compound 1 shown in green sticks, (B) compound 2 shown in green sticks; (C) compound 3 shown in green sticks, (D) compound 4 shown in green sticks. 
Table 6. Binding free energy $(\mathrm{kcal} / \mathrm{mol})$ and its components of docked compounds to the protein target.

\begin{tabular}{ccccc}
\hline Compound & $\boldsymbol{\Delta G}_{\text {bind }}$ & $\mathbf{E}_{\text {ele }}$ & $\mathbf{E}_{\mathbf{v d w}}$ & $\mathbf{E}_{\text {sol }}$ \\
\hline $\mathbf{1}$ & -38.59 & -94.21 & -33.61 & 89.23 \\
\hline $\mathbf{1 a}$ & -23.65 & -92.54 & -18.71 & 87.6 \\
\hline $\mathbf{2}$ & -33.95 & -75.89 & -29.02 & 70.96 \\
\hline $\mathbf{3}$ & -34.01 & -68.58 & -29.51 & 64.08 \\
\hline $\mathbf{4}$ & -29.32 & -70.64 & -25.32 & 66.64 \\
\hline $\mathbf{5}$ & -26.57 & -111.25 & -23.41 & 108.08 \\
\hline $\mathbf{6}$ & -27.74 & -63.78 & -22.78 & 58.82 \\
\hline $\mathbf{7}$ & -40.47 & -81.75 & -36.67 & 77.95 \\
\hline $\mathbf{7 a}$ & -24.67 & -39.34 & -21.48 & 36.15 \\
\hline $\mathbf{9}$ & -29.83 & -155.19 & -24.87 & 150.22 \\
\hline $\mathbf{9 b}$ & -28.49 & -56.25 & -23.83 & 51.59 \\
\hline
\end{tabular}

Comparing the docking pose of compound $\mathbf{1}$ (Figure 5A) and its vobasinyl moiety (1a, Figure S29A), we observe that the indole $\mathrm{NH}$ of compound $\mathbf{1}$ rather makes a H-bond interaction with Asp284, while the ester group interacts with the Asn249. The former is absent in the interaction between 1a and the binding site, this moiety only interacting via H-bonding with Ala114. When compared with compound 7, the isomer of compound 1, the vobasinyl moiety (7a) only interacts with Asn249 and not with the triad, while when the entire compound 7 was docked, the ester group rather interacted with the triad and not with the Asn249 (Figure S29D). We must, however, note that moiety $7 \mathbf{a}$ is the geometric isomer of moiety $\mathbf{1 a}$, while compound $\mathbf{2}$ is equivalent to the iboga unit of compound 7 and compound 3 is the iboga unit of compound 8 . One could also explain the much higher activities of the bisindoles when compared with the mono indoles, because the mono indoles generally lack the vobasinyl units, thus missing the right interactions in the binding site. This could be because this part of the molecule does not interact with the aforementioned residues, the two compounds ( $\mathbf{1}$ and $\mathbf{7})$ almost binding in the same way (yellow structures of Figure 5A and Figure S30A).

In terms of docking scores (Table 5), all bisindoles (the most active compounds, except the untested compound 9) had higher docking scores $(-4.25,-4.25$ and $-4.72 \mathrm{kcal} / \mathrm{mol})$ for compounds 1, 7 and 8, respectively, towards the docked receptor. When compared with the monoindoles (ranging from -4.79 to $-5.26 \mathrm{kcal} / \mathrm{mol}$ ), the docking scores of the monoindoles are much lower. It must be noted that the stereoisomers $\mathbf{1}$ and $\mathbf{7}$ had the same docking scores $(-4.25 \mathrm{kcal} / \mathrm{mol})$ towards the receptor site, an indication that the difference in stereochemistry had no effects on the top scoring docking poses. All the indoles had higher docking scores towards the receptor site, when compared with the reference compound auranofin $(-6.37 \mathrm{kcal} / \mathrm{mol})$, but this could be explained by the fact that this compound could have a completely different binding mode or even different binding site from the reported Voacanga indoles. The chemical structure of auranofin (PubChem ID: 24199313) is shown in the Supplementary Data (Figure S28). A similar trend could be seen in terms of the minimization energies of the ligand-receptor complexes (Table 5), except for compound 8 (which had a much higher minimization energy $(-28.41 \mathrm{kcal} / \mathrm{mol}$ ), when compared with its other bisindole counterparts ( 1 and $\mathbf{7})$, with minimizations energies of -30.48 and $-30.43 \mathrm{kcal} / \mathrm{mol}$, respectively. When compared with the monoindoles (compounds 2 to 4), the minimization energies of the complexes with bisindoles are much lower (more stable) than those with monoindoles. It was generally observed that the isolated molecules bound almost mostly via hydrophobic interactions with amino acid sidechains in the O. ochengi thioredoxin reductase target site. In terms of binding free energies, although no clear SAR could be derived, it was observed that electrostatic contributions 
towards the binding of the compounds towards the target were more important than van der Waals interactions.

\section{Materials and Methods}

\subsection{General Experimental Procedures}

Column chromatography was carried out with glass columns using Merck 60 (Merck,

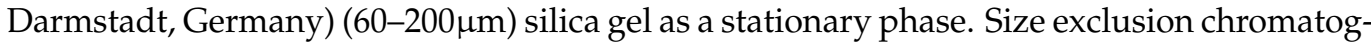
raphy was performed with Sephadex LH-20 (Sigma Aldrich, Seelze, Germany). Preparative TLC was performed using silica gel H. Analytical TLC was performed on Merck F254 aluminium sheets precoated with silica gel with $n$-hexane in ethyl acetate as the mobile phase. Triethylamine was added in the mobile phase to prevent interaction of the basic alkaloids with acidic silanol groups of the silica gel packing material. Zones on these plates were visualized under UVGL-58 lamp (Analytica Jena, Upland, CA, USA) at 254/365 nm and then sprayed with Dragendoff's reagent. The purity of the compounds was determined using RP-C18 column with analytical Shimadzu HPLC 2017 (Shimadzu Corporation, Kyoto, Japan)) with a photodiode array detector. $\mathrm{A}_{3} \mathrm{PO}_{4} / \mathrm{K}_{2} \mathrm{HPO}_{4}$ buffer ( $\mathrm{pH}$ 6.0) with mobile phase 4:6 $\left(\mathrm{CH}_{3} \mathrm{CN} / \mathrm{H}_{2} \mathrm{O}\right)$ was used for the separation. Melting points were determined on a Mel Temp II apparatus (Merck, Darmstadt, Germany) and are uncorrected. Optical rotation was determined using an ADP430 digital polarimeter (Bellingham and Stanley, Tunbridge Wells, UK) at $20^{\circ} \mathrm{C}$ using the sodium D line ( $\left.589 \mathrm{~nm}\right)$. IR spectroscopy was performed on a Spectrum 2 FT-IR spectrometer (PerkinElmer, Waltham, MA, USA) with a UATR accessory. Mass spectrometry was performed using a Xevo G2-S mass spectrometer (Waters, Elstree, UK) equipped with an atmospheric solids analysis probe, in positive ion mode. ${ }^{1} \mathrm{H}$ - and ${ }^{13} \mathrm{C}$-NMR spectra were recorded in $\mathrm{CDCl}_{3}$ at 500 and $125 \mathrm{MHz}$, respectively, with TMS as the internal reference, using an AVANCE III $500 \mathrm{MHz}\left({ }^{1} \mathrm{H}\right)$ NMR spectrometer equipped with a BBFO probe (Bruker, Billerica, MA, USA). The chemical shifts $(\delta)$ of carbon and proton are in parts per million.

\subsection{Plant Material}

The stem barks of $V$. africana Stapf (Apocynaceae) were collected in Ndop, North West Region of Cameroon, in October 2014 by Dr. Wirmum Clare, Director of the Medicinal Foods and Plants, Bamenda. A voucher specimen of the plant, $\mathrm{N}^{\circ}$ SCA887, was deposited at the Limbe Botanic Garden.

\subsection{Extraction and Isolation}

The fresh stem barks of $V$. africana were air-dried and ground into coarse powder. The powdered sample of the plant was macerated in methanol at room temperature for nine days $(3 \times 3$ days). Filtration and concentration of the crude extract led to a dark greenish extract. The crude extract was subjected to silica gel normal phase open column chromatography and elution with a gradient of ethyl acetate in hexane. Repeated column chromatography and purification through Sephadex LH-20 and preparative TLC yielded the compounds 1-9.

\subsection{In Vitro Antimalarial Activity}

\subsubsection{Isolation of Onchocerca ochengi Adult Worms}

The isolation of $O$. ochengi adult worms was performed as described previously by Cho-Ngwa et al. [26]. Briefly, fresh pieces of umbilical cattle skin with palpable nodules bought from butchery in Douala, Cameroon were washed, drained and sterilized with $70 \%$ ethanol. The worms were carefully scraped out of the nodules as single masses and temporarily submerged in $1 \mathrm{~mL}$ complete culture medium, CCM [RPMI-1640 (SigmaAldrich, St. Louis, MO, USA) supplemented with $25 \mathrm{mM}$ HEPES, $2 \mathrm{~g} / \mathrm{L}$ sodium bicarbonate, $2 \mathrm{mM}$ L-glutamine, 5\% newborn calf serum (SIGMA, St. Louis, MO, USA), 150 units $/ \mathrm{mL}$ penicillin, $150 \mu \mathrm{g} / \mathrm{mL}$ streptomycin and $0.5 \mu \mathrm{g} / \mathrm{mL}$ amphotericin B (SIGMA, St. Louis, MO, USA), pH 7.4)] using 24-well plates. The adult worms were incubated in the culture 
medium overnight in a $\mathrm{CO}_{2}$ incubator, during which period the male worms migrated out of the nodular masses. Only wells containing viable worms received treatment with test compounds. Damaged worms and worms from putrefied nodules were discarded. The viability of worms retained for the assay was ascertained by visual and microscopic examination of adult male worm motility using an inverted microscope.

\subsubsection{Mammalian Cells for Microfilarial Cultures and Cytotoxicity Studies}

Monkey kidney epithelial cells (LLC-MK2) (ATCC, Manassas, VA, USA) were cultured at $37{ }^{\circ} \mathrm{C}$ in humidified air with $5 \% \mathrm{CO}_{2}$ in a Hera Cell-150 incubator (Thermo Electron, Karlsruhe, Germany) until the cell layer was almost confluent. The cell suspension was dispensed into 96-well micro titer plates $(200 \mu \mathrm{L} /$ well) and kept in the incubator for 35 days for cells to grow and become fully confluent. These cells served as feeder layers for the Mf assays and were also used for cytotoxicity studies.

\subsubsection{Isolation and Culturing of Onchocerca ochengi Microfilariae}

Briefly, Mf were prepared using the method described by Cho-Ngwa et al. [26], with slight modifications. A few skin snips were obtained from different locations and incubated in aliquots of culture medium for $15 \mathrm{~min}$, after which the emergent Mf were qualified and quantified using an inverted microscope and standard atlases. The leftover pieces of skin were shaved, rinsed, sterilized with $70 \%$ ethanol and sliced into thin slivers. The slivers were incubated in CCM for $2 \mathrm{~h}$, and the emergent highly motile O. ochengi Mf were concentrated by centrifugation. The Mf were transferred to 96-well micro titer plates (15 Mf/100 $\mu \mathrm{L} /$ well) containing a fully confluent LLC-MK2 cell layer in $100 \mu \mathrm{L}$ of CCM. This was monitored for viability and sterility for $24 \mathrm{~h}$ before addition of test and control compounds.

\subsubsection{Preparation of Loa loa Microfilariae}

For the confirmation of the presence of L. loa Mf, a thick blood smear was prepared, stained with Giemsa and observed under a light microscope [26]. Ten milliliters of venous blood was collected in EDTA tubes and gently mixed. A portion of the blood was diluted in RPMI-1640 medium, and the Mf load was determined using an inverted microscope. The blood was then diluted according to the number of Mf present at initial count so as to obtain a total of $15 \mathrm{Mf} / 100 \mu \mathrm{L} /$ well. After dilution, the Mf were transferred in a 96-well plate and monitored for $24 \mathrm{~h}$ before the addition of test and control compounds.

\subsubsection{Primary and Secondary Screens against Onchocerca ochengi Adult Worms}

The compounds were tested on Mfs at a single concentration of $30 \mu \mathrm{M}$, in duplicate wells. The worm cultures containing the drug were incubated for $168 \mathrm{~h}$ (7 days), at $37^{\circ} \mathrm{C}$ in $5 \% \mathrm{CO}_{2}$ atmosphere. The female worms were removed and incubated in $500 \mu \mathrm{L}$ of $0.5 \mu \mathrm{g} / \mathrm{mL}$ MTT for the last $30 \mathrm{~min}$ of incubation. Inhibition of formazan formation from MTT directly correlates with worm death. The worms were blotted on absorbent paper and observed visually for blue coloration against a white background. Scores based on activity were assigned, ranging from $100 \%$ inhibition of formazan formation giving a completely pale yellow worm, $90 \%$ inhibition giving only one or few spots of blue color seen on the worm, $75 \%$ inhibition where about $75 \%$ of the worm remained pale yellow, $50 \%$ where about $50 \%$ of the worm remained pale yellow, to $25 \%$ giving near total blue coloration, and $0 \%$ (inactive compound) for total blue color on worm. Auranofin at $10 \mu \mathrm{M}$, which had previously shown activity against $O$. ochengi adult worms and Mf [27], was used as a positive control, while negative control wells received the diluent, $2 \%$ DMSO only, previously shown to have no effect on parasite viability. The solvent DMSO (2\%) was used as a negative control. In addition, the $2 \%$ DMSO concentration has been shown to be nontoxic to worms and LLCMK2 cells in vitro [26,36]. Furthermore, the toxicity of DMSO decreases with dilution [37]. 
Adult male worm motility was evaluated with the aid of an inverted microscope. Motility score was on a scale of 4 (vigorous or normal movement of whole worm, corresponding to $0 \%$ inhibition of worm motility), 3 (near normal movement of whole worm or $25 \%$ inhibition of worm motility), 2 (whole body of worm motile but sluggish, i.e., $50 \%$ inhibition of worm motility), 1 (only head or tail of worm moving, i.e., $75 \%$ inhibition of worm motility) and 0 (completely immotile worm, i.e., $100 \%$ inhibition of worm motility). A metabolite was considered active if there was a $100 \%$ inhibition of adult male worm motility, or moderately active for a motility inhibition of $50-99 \%$, and inactive if the inhibition was less than $50 \%$.

The pure compounds with $100 \%$ activity at primary screens were re-tested as described under primary screens, in order to determine the $\mathrm{IC}_{50}$ values. The $\mathrm{IC}_{50}$ assays were performed in triplicate and each experiment repeated for confirmation. The means of all activities at a concentration were calculated and used in the statistical analyses. GraphPadPrism version 6.0 (GraphPad Software, San Diego, CA, USA) was used to generate dose response curves from which the $\mathrm{IC}_{50}$ values were obtained.

\subsubsection{Primary and Secondary Screens against Onchocerca ochengi Microfilariae}

The biological assays were conducted in duplicate in the 96-well microtiter plates. The Mf were incubated with the drug for $120 \mathrm{~h}$ in a total of $200 \mu \mathrm{L}$ of medium. Mf viability was assessed by microscopy once every day and motility inhibition scores were recorded. The drug activity was determined using the data of the 5th day. Motility inhibition correlates to drug activity. The positive control drug was amorcazine at $30 \mu \mathrm{M}$, and negative control was the diluent (DMSO).

Compounds showing $100 \%$ activity in the primary screens were re-tested as described under primary screens to determine the $\mathrm{IC}_{50}$ values. All assays were repeated at least once. The selectivity index (SI) of each extract was calculated as the ratio of the $\mathrm{IC}_{50}$ of the extract on the mammalian cell (termed $\mathrm{CC}_{50}$ ) to the $\mathrm{IC}_{50}$ on parasites.

\subsubsection{Screens against Loa loa Microfilariae}

Ethical clearance for the study was obtained from the Cameroon National Ethics Committee, while patients freely gave their written consent to participate in the study before recruitment. Clients living in the Edea Health District were invited to the Edea District Hospital for free screening. All the compounds were screened against L. loa $\mathrm{Mf}$ and the $\mathrm{IC}_{50}$ values determined. This was performed according to the protocol used to screen extracts against $O$. ochengi $\mathrm{Mf}$. All assays were repeated at least once for confirmation of results.

\subsubsection{Cytotoxicity Studies}

Cytotoxicity of the pure compounds with anti-onchocercal activities was assessed on LLC-MK2 cells, microscopically, on day 5 of the Mf assay. Living cells were flattened out and attached to the culture plate, while dead cells were rounded up and detached from the plate. The $\mathrm{IC}_{50}$ values for these cells were estimated from the morphological deformation data.

\subsubsection{Statistical Analysis}

The statistical significance of differences in means between the effects of pure compounds at various concentrations on parasites were determined by one-way analysis of variance (ANOVA), followed by Newman-Keuls multiple comparison tests. A value of $p<0.05$ was considered significant. The data were analyzed using GraphPadPrism 6.

\subsection{Molecular Modeling}

In this study, it was unclear why the compounds exhibited anti-onchocercal activities. An attempt to explore the mode of action of these compounds and to explore the structure- 
activity relations led to docking all of them in the same active site as the reference compound in the study.

\subsubsection{Homology Modeling}

The choice of the target thioredoxin reductase is based on the fact that the reference compound in the bioassays (Auranofin) is a known inhibitor of Onchocerca volvulus thioredoxin reductase [27]. Amino acid sequences of the target proteins were retrieved from several UniProt databases (https:/ / www.uniprot.org/uniprot/I7IAK1) [38]. For the identification of the candidate template structures, a BLAST [39] search of the full-length target sequence was carried out using the RCSB Protein Data Bank [40]. The final template structures were chosen based on the sequence identity, the quality of the available structural data and the type of the bound ligand. Sequence identity and similarity of the templates and target proteins were calculated in MOE (Figure S24, Supplementary Data). The initial sequence alignment for modeling was performed in MOE software version 16.08 (Montreal, QC, Canada) [41]. The template structure and/or the initial alignment were manually adjusted before the modeling to address conserved structural features of the binding pocket. The homology modeling of the target protein catalytic domains was performed using the program MODELLER 9.11 (San Francisco, CA, USA) [42]. Choice of homology model was based on the DOPE score implemented in the modeler program.

\section{Molecular Dynamic Simulation of the Generated Homology Model}

The generated homology model was subjected to molecular dynamics (MD) simulations using the AMBER16 program (San Francisco, CA, USA) to evaluate its stability [35]. The tleap module in amber was used to prepare the system for MD simulations. Hydrogen atoms were added to all amino acid residues assuming a normal ionization state for all ionizable residues. The ff03.r1 force field was used to optimize the protein, while the tip3p for water model was used to solvate the entire system in an octahedral box [43]. The solute atoms and the borders of the box were separated by at least $10 \AA$.

The resulting system was then energy minimized in two steps: a 3000 step minimization (2000 cycles of steepest descent followed by 1000 cycles of conjugate gradient) with restraints on the protein atoms, while the solvent molecules and counter ions were free. This was followed by a further 4000 cycle minimization of the entire system (2000 cycles of steepest descent followed by 2000 cycles of conjugate gradient) without restraints to remove any steric clash in the initial geometry of the protein. Subsequently, restraint heating of the system using a force constant of $10 \mathrm{kcal} / \mathrm{mol}$ from 0 to $300 \mathrm{~K}$ was performed over a period of 100 ps. Finally, using the Particle Mesh Ewald method, we ran a 20 ns molecular dynamic simulation using a time step of $2 \mathrm{fs}[44,45]$. The system was kept at constant temperature $(300 \mathrm{~K})$ and pressure $(1 \mathrm{bar})$ during the molecular dynamic simulation time. Distances and rmsd were calculated with respect to the input coordinates of the complex as a reference using cpptraj.

\subsubsection{Protein Preparation}

Based on the generated homology models, the best model was selected (with regard to the lowest DOPE score) and subsequently used in this study. Protein preparation was performed using similar protocols previously reported by Simoben et al., 2018 [46]. Protein Preparation Wizard of Schrödinger software (New York, NY, USA) using the default settings was used to prepare the protein structure [47]. The Epik-tool (with the $\mathrm{pH}$ set at $7.0 \pm 2.0$ ) was used to apply bond orders, and hydrogen atoms and protonation of the heteroatom states were added using optimization of the H-bond network. The structure was finally subjected to a restrained energy minimization step using the Optimized Potentials for Liquid Simulations (OPLS) 2005 force field [48] and a root-mean-square-deviation (rmsd) of $0.3 \AA$ for atom displacement for terminating. 


\subsubsection{Ligand Dataset Preparation}

Schrodinger software, v2017-u1 was used for the preparation of ligands for docking [49]. The Epik ionization method at biologically relevant $\mathrm{pH}(\mathrm{pH} 7.0 \pm 2.0)$ was used to generate all possible tautomers, as well as possible combinations of stereoisomers for molecules without well-defined stereochemistry. Additionally, the optimized integrated OPLS_2005 force field [48] was used to minimize all ligands. Finally, 30 conformers for each of the prepared ligand molecules were generated and each conformer output minimized using the settings of ConfGen [50,51].

\subsubsection{Ligand Docking and Scoring}

Prepared protein and ligands were flexibly docked using the standardized Glide program procedure of Schrödinger's software [49,51]. The receptor grid preparation for the docking procedure was carried out by assigning the center of the transferred ligand from the template into our homology model (FDA) as the centroid of the grid box. Glide docking program in Schrodinger software was subsequently used to dock the generated threedimensional conformers of the prepared ligand. The GlideScore (GS) Standard Precision (SP) mode was used as the scoring function to rank the resulting binding poses [49,52]. A total of 5 poses per ligand conformer were included in the post-docking minimization step, and a maximum of 2 docking poses was generated for each ligand conformer.

\subsubsection{Rescoring Docked Poses by Binding Free Energy Calculations}

This was performed via a complex minimization approach using the molecular mechanics energies combined with the generalized Born and accessible surface area (MMGBSA) implicit continuum solvation [53,54] with the AMBER12EHT force field [55] implemented in MOE [41] to estimate the binding free energy (BFE) for the proposed poses after docking of each molecule. AMBER12EHT force field was used to fix partial charges for each of Protonate3D system [56] followed by a short minimization. Finally, an in-house script for MOE was used to estimated BFE for all the docked poses. Protein heavy atoms were tethered during complex minimization with a deviation of $0.5 \AA$ (force constant $(3 / 2)$ $\left.\mathrm{kT} /(0.5)^{2}\right)$.

\section{Conclusions}

A new bisindole iboga-vobasine type alkaloid named voacamine A (1) along with eight known compounds, voacangine (2), voacristine (3), coronaridine (4), tabernanthine (5), ibogaine (6), voacamine (7), voacorine (8) and conoduramine (9) were isolated from the stem barks of Voacanga africana. All compounds were tested for their anti-onchocercal activity against the O. ochengi. Compounds $\mathbf{1 - 4}$ and $\mathbf{6 - 8}$ were found to inhibit the motility of both the Mf and adult male worms of Onchocerca ochengi, in a dose-dependent manner, but were only moderately active on the adult female worms upon biochemical assessment at $30 \mu \mathrm{M}$ drug concentrations. Their $\mathrm{IC}_{50}$ values are $2.49-5.49 \mu \mathrm{M}$ for $\mathrm{Mf}$ and $3.45-17.87 \mu \mathrm{M}$ for adult males. This study reports, for the first time, the efficacy of these alkaloids against $\mathrm{Mf}$ and adult $O$. ochengi worms. Molecular modeling led to the generation of a homology model for the $O$. ochengi thioredoxin reductase target. It was, however, unclear why the compounds exhibited anti-onchocercal activities. An attempt to explore the mode of action of these compounds and to explore the structure-activity relations led to docking all of them in the same active site as the reference compound in the study. Since the reference compound is known to bind to the aforementioned drug target, our rationale was to attempt an initial SAR study by exploring the putative binding of these compounds to the target in silico, then further suggest an in vitro study of the enzyme inhibition kinetics of these compounds against the target. Docking the receptor site could offer an explanation for the structure-activity relationships of the isolated compounds in terms of docking scores, binding free energies towards the drug target site, complex minimization energies and interactions with site chain residues. 
Supplementary Materials: The following are available online, Figure S1: IR spectrum of voacamine A, Figure S2: Mass spectrum of voacamine A, Figure S3: ${ }^{1} \mathrm{H}-\mathrm{NMR}\left(500 \mathrm{MHz}, \mathrm{CDCl}_{3}\right)$ spectrum of voacamine A, Figure S4: ${ }^{13} \mathrm{C}-\mathrm{NMR}\left(125 \mathrm{MHz}, \mathrm{CDCl}_{3}\right)$ spectrum of voacamine A, Figure S5: ${ }^{1} \mathrm{H}-{ }^{1} \mathrm{H}$ COSY spectrum of voacamine A, Figure S6: ${ }^{1} \mathrm{H}-{ }^{1} \mathrm{H}$ NOESY spectrum of voacamine A, Figure S7: ${ }^{1} \mathrm{H}_{-}{ }^{1} \mathrm{H}$ HSQC spectrum of voacamine A, Figure S8: ${ }^{1} \mathrm{H}_{-}{ }^{1} \mathrm{H}$ HSQC and ${ }^{1} \mathrm{H}_{-}{ }^{13} \mathrm{C}$ HMBC spectra of voacamine A, Figure S9: ${ }^{1} \mathrm{H}_{-}{ }^{15} \mathrm{~N}-\mathrm{HSQC}$ and ${ }^{1} \mathrm{H}_{-}{ }^{15} \mathrm{~N}-\mathrm{HMBC}$ spectra of voacamine A, Figure S10: ${ }^{1} \mathrm{H}-$ NMR $\left(500 \mathrm{MHz}, \mathrm{CDCl}_{3}\right.$ ) spectrum of voacangine, Figure S11: ${ }^{13} \mathrm{C}-\mathrm{NMR}\left(125 \mathrm{MHz}, \mathrm{CDCl}_{3}\right)$ spectrum of voacangine, Figure S12: ${ }^{1} \mathrm{H}-\mathrm{NMR}\left(500 \mathrm{MHz}, \mathrm{CDCl}_{3}\right)$ spectrum of voacristine, Figure S13: ${ }^{13} \mathrm{C}$ NMR $\left(125 \mathrm{MHz}, \mathrm{CDCl}_{3}\right)$ spectrum of voacristine, Figure S14: ${ }^{1} \mathrm{H}-\mathrm{NMR}\left(500 \mathrm{MHz}, \mathrm{CDCl}_{3}\right)$ spectrum of coronaridine, Figure S15: ${ }^{13} \mathrm{C}-\mathrm{NMR}\left(125 \mathrm{MHz}, \mathrm{CDCl}_{3}\right)$ spectrum of coronaridine, Figure S16: ${ }^{1} \mathrm{H}-\mathrm{NMR}\left(500 \mathrm{MHz}, \mathrm{CDCl}_{3}\right)$ spectrum of tabernanthine, Figure S17: ${ }^{13} \mathrm{C}-\mathrm{NMR}\left(125 \mathrm{MHz}, \mathrm{DMSO}-\mathrm{d}_{6}\right)$ spectrum of tabernanthine, Figure S18: ${ }^{1}$ - NMR (500 MHz, MeOD) spectrum of iboxygaine, Figure S19: ${ }^{13} \mathrm{C}-\mathrm{NMR}\left(125 \mathrm{MHz}, \mathrm{CDCl}_{3}\right)$ spectrum of iboxygaine, Figure S20: ${ }^{1} \mathrm{H}-\mathrm{NMR}(500 \mathrm{MHz}, \mathrm{DMSO}-$ $\mathrm{d}_{6}$ ) spectrum of voacamine, Figure S21: ${ }^{13} \mathrm{CNMR}\left(125 \mathrm{MHz}, \mathrm{DMSO}-\mathrm{d}_{6}\right)$ spectrum of voacamine, Figure S22: ${ }^{1} \mathrm{H}-\mathrm{NMR}\left(500 \mathrm{MHz}, \mathrm{CDCl}_{3}\right)$ spectrum of voacorine, Figure S23: ${ }^{13} \mathrm{C}-\mathrm{NMR}(125 \mathrm{MHz}$, $\mathrm{CDCl}_{3}$ ) spectrum of voacorine, Figure $\mathrm{S} 24:{ }^{1} \mathrm{H}-\mathrm{NMR}\left(500 \mathrm{MHz}, \mathrm{CDCl}_{3}\right)$ spectrum of conoduramine, Figure S25: ${ }^{13} \mathrm{C}-\mathrm{NMR}\left(125 \mathrm{MHz}, \mathrm{CDCl}_{3}\right)$ spectrum of conoduramine, Figure S26: Percentage sequence identity and similarity values to our target, Figure S27: Ramachandran plot $(\varphi / \psi)$ distribution of the backbone conformation, Figure S28: Chemical structure of auranofin, Figure S29: Docking poses of (A) compound 1a, (B) compound 5, (C) compound 6, (D) compound 7a, Figure S30: Docking poses of (A) compound 7, (B) compound 8, (C) compound 9, (D) compound 9b.

Author Contributions: Conceptualization, J.A.M., K.O.A. and F.N.-K.; Data Curation, S.B.B., C.V.S., R.K., H.M., E.J.L. and F.N.-K.; Formal Analysis, R.K., E.J.L. and F.N.-K.; Funding acquisition, S.B.B., K.O.A., F.N.-K., E.J.L., R.K., F.C.-N., J.A.M. and W.S.; Investigation, S.B.B., C.V.S., E.M., R.K., D.O. and E.J.L.; Methodology, S.B.B., E.M., C.V.S., H.M. and E.J.L.; Project administration, J.A.M, K.O.A., W.S. and E.L.J.; Software, W.S.; Supervision, J.A.M, K.O.A, W.S., E.J.L. and F.N.-K; Validation, S.B.B., C.V.S., E.J.L. and F.N.-K.; Visualization, C.V.S., F.N.-K., E.J.L. and S.B.B.; Writing-original draft, S.B.B., E.J.L., C.V.S., K.O.A. and F.N.-K.; Writing-review and editing, J.A.M., D.O., H.M., E.M., F.C.-N., R.K. and W.S. All authors have read and agreed to the published version of the manuscript.

Funding: We acknowledge the financial support from Africa Regional International Staff/Student Exchange: Food Security and Sustainable Human Wellbeing (ARISE) and Ministry of Higher Education of Cameroon (MINESUP) to S.B.B to carry out part of his PhD research work at the University of Nairobi, Kenya. We are also grateful to the African-German Network of Excellence in Science (AGNES) junior researcher grant awarded to S.B.B in 2019. F.N.-K. would also like to acknowledge funding from the German Academic Exchange Services (DAAD) for a guest professorship at TU Dresden.

Institutional Review Board Statement: Ethical Clearance Decision No. 2015/12/679/CE/CNERSH/SP of Ministry of Public Health, Cameroon dated 16 December 2016.

Informed Consent Statement: Informed consent was obtained from all subjects involved in the study.

Data Availability Statement: Data is contained within the article or supplementary material.

Acknowledgments: We thank Michael Spiteller of the Institute of Environmental Research (INFU) of the Faculty of Chemistry, Chair of Environmental Chemistry and Analytical Chemistry, TU Dortmund, Dortmund, Germany for LC-MS and NMR analyses of some of the compounds. We also thank the National Mass Spectrometry Facility at Swansea University for MS analysis of voacamine A.

Conflicts of Interest: The authors declare no conflict of interest.

Sample Availability: Samples of the compounds 1-9 are available from the authors.

\section{References}

1. Tona, L.; Kambu, K.; Mesia, K.; Cimanga, K.; Apers, S.; De Bruyne, T.; Pieters, L.; Totte, J.; Vlietinck, A.J. Biological screening of traditional preparations from some medicinal plants used as antidiarrhoeal in Kinshasa, Congo. Phytomedicine 1999, 6, 59-66. [CrossRef]

2. Liu, X.; Yanga, D.; Liu, J.; Ren, N. Synthesis and acetylcholinesterase inhibitory activities of tabersonine derivatives. Phytochem. Lett. 2015, 14, 17-22. [CrossRef] 
3. Chen, H.M.; Yang, Y.T.; Li, H.X.; Cao, Z.X.; Dan, X.M.; Mei, L.; Guo, D.L.; Song, C.X.; Dai, Y.; Hu, J.; et al. Cytotoxic monoterpenoid indole alkaloids isolated from the barks of Voacanga africana Staph. Nat. Prod. Res. 2016, 30, 1144-1149. [CrossRef] [PubMed]

4. Tan, P.V.; Nyasse, B. Anti-ulcer compound from Voacanga africana with possible histamine $\mathrm{H}_{2}$ receptor blocking activity. Phytomedicine 2000, 7, 509-515. [CrossRef]

5. Tan, P.V.; Penlap, V.B.; Nyasse, B.; Nguemo, J.D.B. Anti-ulceractions of the bark methanol extract of Voacanga africana in different experimental ulcer models in rats. J. Ethnopharmacol. 2000, 73, 423-428. [CrossRef]

6. Jiofack, T.; Fokunang, C.; Kemeuze, V.; Fongnzossie, E.; Tsabang, N.; Nkuinkeu, R.; Mapongmetsem, P.M.; Nkongmeneck, B.A. Ethnobotany and phytopharmacopoea of the South-West ethnoecological region of Cameroon. J. Med. Plants Res. 2008, 2, 197-206.

7. Hussain, H.; Hussain, J.; Al-Harrasi, A.; Green, I.R. Chemistry and biology of the genus Voacanga. Pharm. Biol. 2012, 50, 1183-1193. [CrossRef] [PubMed]

8. Kitajima, M.; Iwai, M.; Kogure, N.; Kikura-Hanajiri, R.; Goda, Y.; Takayama, H. Aspidosperma-aspidosperma-type bisindole alkaloids from Voacanga africana. Tetrahedron 2013, 69, 796-801. [CrossRef]

9. Dey, A.; Mukherjee, A.; Chaudhury, M. Alkaloids from Apocynaceae: Origin, pharmacotherapeutic properties, and structureactivity studies. Stud. Nat. Prod. Chem. 2017, 52, 373-487.

10. Rao, K.V. Alkaloids of Voacanga africana, Stapf. I. voacafrine and voacafricine-two new alkaloids. J. Org. Chem. 1958, 23, 1455-1456. [CrossRef]

11. Kitajima, M.; Iwai, M.; Kikura-Hanajiri, R.; Goda, Y.; Iida, M.; Yabushita, H.; Takayama, H. Discovery of indole alkaloids with cannabinoid CB1 receptor antagonistic activity. Bioorg. Med. Chem. 2011, 21, 1962-1964. [CrossRef] [PubMed]

12. Kitajima, M.; Takayama, H. Monoterpenoid bisindole alkaloids. Alkaloids 2016, 76, 259-310.

13. Borakaeyabe, S.B.; Mbah, J.A.; Cho-Ngwa, F.; Metuge, J.A.; Efange, S.M.N. Isolation and characterization of filaricidal compounds from the stem bark of Voacanga africana, a plant used for onchocerciasis in Cameroon. J. Med. Plants Res. 2015, 9, 471-478.

14. Trees, A.; Graham, S.; Renz, A.; Bianco, A.; Tanya, V. Onchocerca ochengi infections in cattle as a model for human onchocerciasis: Recent developments. Parasitology 2000, 120, 133-142. [CrossRef]

15. Lobos, E.; Weiss, N.; Karam, M.; Taylor, H.R.; Ottesen, E.A.; Nutman, T.B. Animmunogenic Onchocerca volvulus antigen: A specific and early marker of infection. Science 1991, 251, 1603-1605. [CrossRef]

16. Harada, M.; Asaba, K.N.; Iwai, M.; Kogure, N.; Kitajima, M.; Takayama, H. Asymmetric total synthesis of an iboga-type indole alkaloid, voacangalactone, newly isolated from Voacanga africana. Org. Lett. 2012, 14, 5800-5803. [CrossRef]

17. Kutney, J.P.; Horinaka, A.; Ward, R.S.; Worth, B.R. Studies on the total synthesis of bisindole alkaloids within the voacamine family. Can. J. Chem. 1980, 58, 1829-1838. [CrossRef]

18. Medeiros, W.L.B.; Vieira, I.J.C.; Mathias, L.; Braz-Filho, R.; Leal, K.Z.; Rodrigues-Filho, E.; Schripsema, J. Two known bis-indole alkaloids isolated from Tabernaemontana laeta: Complete ${ }^{1} \mathrm{H}$ and ${ }^{13} \mathrm{C}$ chemical shift assignments. Magn. Reson. Chem. 1999, 37, 676-681. [CrossRef]

19. Nge, C.E.; Chong, K.W.; Thomas, N.F.; Lim, S.H.; Low, Y.Y.; Kam, T.S. Ibogan, a spidosperma, vincamine, and bisindole alkaloids from a Malayan Tabernaemontana corymbosa: Iboga alkaloids with C-20 $\alpha$ substitution. J. Nat. Prod. 2016, 79, 1388-1399. [CrossRef]

20. Sim, D.S.Y.; Teoh, W.Y.; Sim, K.S.; Lim, S.H.; Thomas, N.F.; Low, Y.Y.; Kam, T.S. Vobatensines A-F, cytotoxic iboga-vobasine bisindoles from Tabernaemontana corymbosa. J. Nat. Prod. 2016, 79, 1048-1055. [CrossRef]

21. Zhao, Q.; Zhu, W.-T.; Ding, X.; Huo, Z.-Q.; Donkor, P.O.; Adelakun, T.A.; Hao, X.-J.; Zhang, Y. Voacafrines A-N, aspidospermatype monoterpenoid indole alkaloids from Voacanga africana with AChE inhibitory activity. Phytochemistry 2020, 181, 112566. [CrossRef] [PubMed]

22. Chaturvedula, V.S.P.; Sprague, S.; Schilling, J.K.; Kingston, D.G.I. New cytotoxic indole alkaloids from Tabernaemontana calcarea from the Madagascar rainforest. J. Nat. Prod. 2003, 66, 528-531. [CrossRef] [PubMed]

23. Sharma, P.; Cordell, G.A. Heyneanine hydroxyindolenine, a new indole alkaloid from Ervatamia coronaria var.plena. J. Nat. Prod. 1988, 51, 528-531. [CrossRef]

24. Qu, Y.; Simonescu, R.; Luca, V.D. Monoterpene indole alkaloids from the fruit of Tabernaemontana litoralis and differential alkaloid composition in various fruit components. J. Nat. Prod. 2016, 79, 3143-3147. [CrossRef] [PubMed]

25. Thomas, D.W.; Biemann, K. The hydroxyindolenine derivative of voacangine, a new indole alkaloid from Voacanga africana. Tetrahedron 1987, 24, 4223-4231. [CrossRef]

26. Cho-Ngwa, F.; Abongwa, M.; Ngemenya, N.M.; Nyongbela, K.D. Selective activity of extracts of Margaritaria discoidea and Homalium africanum on Onchocerca ochengi. BMC Complement. Altern. Med. 2010, 10, 62. [CrossRef]

27. Bulman, C.A.; Bidlow, C.M.; Lustigman, S.; Cho-Ngwa, F.; Williams, D.; Rascón, A.A., Jr.; Tricoche, N.; Samje, M.; Bell, A.; Suzuki, B.; et al. Repurposing auranofin as a lead candidate for treatment of lymphatic filariasis and onchocerciasis. PLoS Negl. Trop. Dis. 2015, 9, e0003534. [CrossRef]

28. Gromiha, M.M.; Ahmad, S. Role of solvent accessibility in structure based drug design. Curr. Comput. Aided Drug Des. 2005, 1, 223-235. [CrossRef]

29. Lipinski, C.A.; Lombardo, F.; Dominy, B.W.; Feeney, P.J. Experimental and computational approaches to estimate solubility and permeability in drug discovery and development settings. Adv. Drug Deliv. Rev. 1997, 23, 3-25. [CrossRef]

30. Cavalli, A.; Poluzzi, E.; De Ponti, F.; Recanatini, M. Toward a pharmacophore for drugs inducing the long QT syndrome: Insights from a CoMFA Study of HERG K+ channel blockers. J. Med. Chem. 2002, 45, 3844-3853. [CrossRef] 
31. De Ponti, F.; Poluzzi, E.; Montanaro, N. Organising evidence on QT prolongation and occurrence of Torsades de Pointes with non antiarrhythmic drugs: A call for consensus. Eur. J. Clin. Pharmacol. 2001, 57, 185-209. [CrossRef] [PubMed]

32. Irvine, J.D.; Takahashi, L.; Lockhart, K.; Cheong, J.; Tolan, J.W.; Selick, H.E.; Grove, J.R. MDCK (Madin-Darby canine kidney) cells: A tool for membrane permeability screening. J. Pharm. Sci. 1999, 88, 28-33. [CrossRef] [PubMed]

33. Colmenarejo, G.; Alvarez-Pedraglio, A.; Lavandera, J.-L. Cheminformatic models to predict binding affinities to human serum albumin. J. Med. Chem. 2001, 44, 4370-4378. [CrossRef]

34. Berman, H.M.; Westbrook, J.; Feng, Z.; Gilliland, G.; Bhat, T.N.; Weissig, H.; Shindyalov, I.N.; Bourne, P.E. The Protein Data Bank. Nucleic Acids Res. 2000, 28, 235-242. [CrossRef]

35. Case, D.A.; Betz, R.M.; Cerutti, D.S.; Cheatham, T.E., III; Darden, T.A.; Duke, R.E.; Giese, T.J.; Gohlke, H.; Goetz, A.W.; Homeyer N.; et al. AMBER 2016; University of California: San Francisco, CA, USA, 2016; Available online: https://ambermd.org/ (accessed on 12 November 2020).

36. Cho-Ngwa, F.; Monya, E.; Azantsa, B.K.; Manfo, F.P.T.; Babiaka, S.B.; Mbah, J.A.; Samje, M. Filaricidal activities on Onchocerca ochengi and Loa loa, toxicity and phytochemical screening of extracts of Tragia benthami and Piper umbellatum. BMC Complement. Altern. Med. 2016, 16, 326. [CrossRef] [PubMed]

37. Worthley, E.G.; Schott, C.D. The toxicity of four concentrations of DMSO. Toxicol. Appl. Pharmacol. 1969, 15, 275-281. [CrossRef]

38. The UniProt Consortium. Activities at the Universal Protein Resource (UniProt). Nucleic Acids Res. 2014, 42, D191-D198. [CrossRef]

39. Altschul, S.F.; Gish, W.; Miller, W.; Myers, E.W.; Lipman, D.J. Basic local alignment search tool. J. Mol. Biol. 1990, 215 , 403-410. [CrossRef]

40. Burley, S.K.; Berman, H.M.; Bhikadiya, C.; Bi, C.; Chen, L.; Costanzo, L.D.; Christie, C.; Dalenberg, K.; Duarte, J.M.; Dutta, S.; et al. RCSB Protein Data Bank: Biological macromolecular structures enabling research and education in fundamental biology, biomedicine, biotechnology and energy. Nucleic Acids Res. 2019, 47, D464-D474. [CrossRef]

41. Molecular Operating Environment (MOE), 2016.08; Chemical Computing Group Inc., 1010 Sherbrooke St. West, Suite\#910, Montreal, QC, Canada, H3A 2R7, 2016. Available online: https://www.chemcomp.com/Products.htm (accessed on 12 November 2020).

42. Webb, B.; Sali, A. Comparative protein structure modeling using MODELLER. Curr. Protoc. Bioinform. 2016, 54, 5.6.1-5.6.37.

43. Jorgensen, W.L.; Chandrasekhar, J.; Madura, J.D.; Impey, R.W.; Klein, M.L. Comparison of simple potential functions for simulating liquid water. J. Chem. Phys. 1983, 79, 926-935. [CrossRef]

44. Sagui, C.; Pedersen, L.G.; Darden, T.A. Towards an accurate representation of electrostatics in classical forcefields: Efficient implementation of multipolar interactions in biomolecular simulations. J. Chem. Phys. 2004, 120, 73-87. [CrossRef] [PubMed]

45. Toukmaji, A.; Sagui, C.; Board, J.; Darden, T. Efficient particle-mesh Ewald based approach to fixed and induced dipolar interactions. J. Chem. Phys. 2000, 113, 10913-10927. [CrossRef]

46. Simoben, C.V.; Robaa, D.; Chakrabarti, A.; Schmidtkunz, K.; Marek, M.; Lancelot, J.; Kannan, S.; Melesina, J.; Shaik, T.B.; Pierce, R.J.; et al. A novel class of Schistosoma mansoni histone deacetylase 8 (HDAC8) inhibitors identified by structure-based virtual screening and in vitro testing. Molecules 2018, 23, 566. [CrossRef]

47. Sastry, G.M.; Adzhigirey, M.; Day, T.; Annabhimoju, R.; Sherman, W. Protein and ligand preparation: Parameters, protocols, and influence on virtual screening enrichments. J. Comput. Aided Mol. Des. 2013, 27, 221-234. [CrossRef]

48. Banks, J.L.; Beard, H.S.; Cao, Y.; Cho, A.E.; Damm, W.; Farid, R.; Felts, A.K.; Halgren, T.A.; Mainz, D.T.; Maple, J.R.; et al. Integrated modeling program, Applied Chemical Theory (IMPACT). J. Comput. Chem. 2005, 26, 1752-1780. [CrossRef]

49. Schrodinger. Schrödinger Release 2017-2: LigPrep; Schrödinger, LLC: New York, NY, USA, 2017.

50. Schrodinger. Schrödinger Release 2017-2: ConfGen; Schrödinger, LLC: New York, NY, USA, 2017.

51. Watts, K.S.; Dalal, P.; Murphy, R.B.; Sherman, W.; Friesner, R.A.; Shelley, J.C. ConfGen: A conformational search method for efficient generation of bioactive conformers. J. Chem. Inf. Model. 2010, 50, 534-546. [CrossRef]

52. Halgren, T.A.; Murphy, R.B.; Friesner, R.A.; Beard, H.S.; Frye, L.L.; Pollard, W.T.; Banks, J.L. Glide: A new approach for rapid, accurate docking and scoring. 2. Enrichment factors in database screening. J. Med. Chem. 2004, 47, 1750-1759.

53. Hou, T.; Wang, J.; Li, Y.; Wang, W. Assessing the performance of the MM/PBSA and MM/GBSA methods. 1. The accuracy of binding free energy calculations based on molecular dynamics simulations. J. Chem. Inf. Model. 2011, 51, 69-82. [CrossRef]

54. Genheden, S.; Ryde, U. The MM/PBSA and MM/GBSA methods to estimate ligand-binding affinities. Expert Opin. Drug Discov. 2015, 10, 449-461. [CrossRef]

55. Hornak, V.; Abel, R.; Okur, A.; Strockbine, B.; Roitberg, A.; Simmerling, C. Comparison of multiple AMBER forcefields and development of improved protein backbone parameters. Proteins 2006, 65, 712-725. [CrossRef] [PubMed]

56. Labute, P. Protonate3D: Assignment of ionization states and hydrogen coordinates to macromolecular structures. Proteins 2009, 75, 187-205. [CrossRef] [PubMed] 